\title{
Expected trends and surprises in the Lateglacial and Holocene vegetation history of the Iberian Peninsula and Balearic Islands
}

\author{
José S. Carrión a,*, Santiago Fernández a , Penélope González-Sampériz ${ }^{\text {b }}$, Graciela Gil-Romera ${ }^{\text {c }}$, \\ Ernestina Badal ${ }^{\mathrm{d}}$, Yolanda Carrión-Marco ${ }^{\mathrm{d}}$, Lourdes López-Merino ${ }^{\mathrm{e}}$, José A. López-Sáez ${ }^{\mathrm{e}}$, \\ Elena Fierro ${ }^{a}$, Francesc Burjachs ${ }^{\mathrm{f}}$ \\ a Department of Plant Biology, Faculty of Biology, University of Murcia, 3100 Murcia, Spain \\ b Instituto Pirenaico de Ecología-CSIC, Dpto. Procesos Geoambientales y Cambio Global, Avda.Montañana, 100550059 Zaragoza, Spain \\ c Earth Sciences, The University of Wales, Penglais Campus, Aberystwyth,Ceredigion SY23 3DB, Wales, UK

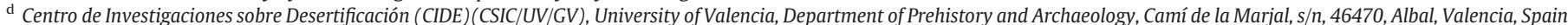 \\ e Research Group of Archaeobiology, History Institute, CCHS, CSIC, Albasanz 26-28, 28037 Madrid, Spain \\ ${ }^{\mathrm{f}}$ Institute of Human Palaeoecology and Social Evolution (IPHES), Institució Catalana de Recerca i Estudis Avançats (ICREA), Plaça Imperial Tarraco, 1, 43005, Tarragona, Spain
}

\section{A R T I C L E I N F O}

\section{Article history:}

Received 30 May 2009

Received in revised form 15 December 2009

Accepted 19 December 2009

Available online 7 January 2010

\section{Keywords:}

palaeoecology

palaeogeography

palaeobotany

Iberia

Quaternary

Holocene

\begin{abstract}
A B S T R A C T
Recent, high-resolution palaeoecological records are changing the traditional picture of post-glacial vegetation succession in the Iberian Peninsula. In addition to the influence of Lateglacial and Early Holocene climatic changes, other factors are critical in the course of vegetation development and we observe strong regional differences. The floristic composition, location and structure of glacial tree populations and communities may have been primary causes of vegetation development. Refugial populations in the Baetic cordilleras would have been a source, but not the only one, for the early Lateglacial oak expansions. From Mid to Late Holocene, inertial, resilient, and rapid responses of vegetation to climatic change are described, and regional differences in the response are stressed. The role of fire, pastoralism, agriculture, and other anthropogenic disturbances (such as mining), during the Copper, Bronze, Iberian, and Roman times, is analysed. The implications of ecological transitions in cultural changes, especially when they occur as societal collapses, are discussed.
\end{abstract}

(c) 2010 Elsevier B.V. All rights reserved.

\section{Introduction}

Over the last few years, the number of Lateglacial and Holocene records in the Iberian Peninsula has increased considerably. This is particularly true in the case of pollen sequences (Carrión et al., 2007; Fletcher et al., 2007; Muñoz-Sobrino et al., 2007; González-Sampériz et al., 2008) and to a lesser extent in the case of anthracological (Badal et al., 2008) and other macrobotanical records (García-Amorena et al., 2007; Postigo et al., 2008). It was only some decades ago that the publication of palaeoecological sequences without absolute dating was relatively frequent (Dupré, 1988; Carrión, 1992; Martínez-Atienza, 1999). However the chronological control of palaeo-records has improved considerably, probably due to the consolidation of research groups and a better access to research funding programmes.

In this context, the present work aims to understand the vegetation change patterns, and their causes, during the Late Quaternary in the Iberian Peninsula and the Balearic Islands. We examine two different time periods: first, the Lateglacial (14,700-11,500 cal. yr BP) and Early

\footnotetext{
* Corresponding author.

E-mail address: carrion@um.es (J.S. Carrión).
}

Holocene (after 11,500 cal. yr BP), when the deglaciation process was concurrent with global warming (Bradley, 2008). In this regard we assess to what extent this multimillennial event was the main controlling factor in the vegetation response, or if instead autoecological processes and high regional topographical variability were more important in regulating the vegetation changes produced (Bennett and Willis, 1995). Our second scenario is defined by the appearance of human activity indicators in the palaeoecological record. The emergence of anthropogenic events is detected in some sequences from the Mid-Holocene while it is delayed in others (Carrión et al., 2009).

This paper is the first attempt to review the topic for the whole of the Iberian Peninsula. This is not an easy task, given the physiographical complexity of this area and the information gaps both in time periods and provinces. We are conscious that the adopted duality (expected versus unexpected) may be considered artificial: making a visual inspection of the palaeo-records reveals that there is a continuum in vegetation histories. However, dichotomizing serves a purpose: separating the histories of directional change through time from those that exhibit apparently accidental trajectories, including those that lack significant change. This approach is a test of how to conceptualize the apparently chaotic picture of vegetational developments (Carrión et al., 2000). Often being too busy with the analytical 
work, we have concentrated on the gaining of new records over the production of theories. But it is our view that observations and theory should be merged and should interact continuously.

\section{Methodological considerations}

We select palaeoecological sequences that exhibit appropriate chronological control of the main vegetation changes at the resolution needed for this paper's goal. These are only a small fraction of those available, because a number of palaeobotanical records were never dated or are based on fragmentary information. In this regard, a good part of the pollen-analytical effort has been in vain. Carrión et al. (2009) have reported failures with Quaternary pollen analyses in the Iberian Peninsula, that is, case studies where it was not possible to extract palynomorphs for pollen counting. Compiled failures included 204 sites, from which 48.8\% were Holocene, and 31.4\% Upper Pleistocene. It is therefore worth pondering what the prevailing paradigm of Late Quaternary vegetation of Iberia would have been had these analyses been successful. As for the study of past fire activity, the lack of continuous, long charcoal sequences prevents any attempt to assess fire regimes and environmental changes at high time resolution. The reconstruction of fire activity is therefore particularly difficult as a consequence of stratigraphical hiatuses in the archaeological sites and the absence of regional information available from charcoal records, in assemblages that are in any case often biased by human selection during harvesting.

An additional problem precluding palaeoenvironmental correlation as well as an adequate regional picture is the absence of open access national databases and repositories as the EPD (European Pollen Database: http://www.europeanpollendatabase.net/) initiative. Some recent proposals such as PALEODIVERSITAS (http://www. paleodiversitas.org/) and LA FLORA EN EL MUNDO IBERICO (http:// www.uv.es/floraiberica) intend to cover this lack of information, although these are still in very preliminary phases. As a consequence of all these aspects, quantitative approaches to regional reconstructions are not available yet.

\section{Palaeoecological indicators}

In order to elucidate the influences and controls on vegetation change, we have largely followed the interpretation given by authors in their publications, especially for detecting the timing of the first anthropogenically-influenced changes. When possible, we have considered palaeoecological bio-indicators from the same sedimentary record studied by pollen and/or macroremains. In the palaeobotanical literature for the Late Quaternary in the Iberian Peninsula, these mainly include:

- Aridity crises: pollen of xerophytes and halophytes (Artemisia, Ephedra, Chenopodiaceae, Lygeum, Lycium, Periploca, Ziziphus, Withania, Sideritis, Tamarix, Aizoaceae), and Pseudoschizaea cysts (Pantaleón-Cano et al., 1996; Burjachs et al., 1997; Carrión and Navarro, 2002; Dorado-Valiño et al., 2002; Carrión et al., 2003; González-Sampériz et al., 2005, 2008; Gil-García et al., 2007; Fletcher et al., 2007; Valero-Garcés et al., 2000a,b, 2004).

- Increased rainfall/reduced summer drought: Botryococcus, Pediastrum, mesophyte pollen, aquatic angiosperm pollen (e.g. Myriophyllum, Potamogeton, Hydrocotyle, Typha, Alisma, Nuphar, Callitriche, Hydrocharis, Lemna, Sparganium), aquatic lycophyte (Isoetes) and fern (e.g. Botrychium, Ophioglossum) spores (LópezSáez et al., 1998; Carrión and van Geel, 1999; Carrión et al., 2001a, 2001b; Carrión, 2002; González-Sampériz et al., 2008, 2009; Valero-Garcés et al., 2008; Moreno et al., 2009.

- Soil erosion: Glomaceae chlamydospores, Pseudoschizaea (Pantaleón-Cano et al., 1996, López-Sáez et al., 2000).
- Trophic conditions: Zygnematales, Desmidiales, Chara gyrogonites, Cyperaceae and Juncus seeds, Protozoa, cyanobacteria (e.g. Gloeotrichia, Rivularia), (Mateus, 1989; López-Sáez et al., 1998, 2000), and several of the non-pollen palynomorphs described by van Geel et al. (1981, 1986, 1989) and Carrión and van Geel (1999) such as Types 119,121 , and several other types.

- Agriculture/arboriculture: Cerealia, Polygonum aviculare, Plantago lanceolata-coronopus, Plantago major-media types, Rumex, Cannabis, Vitis, Puccinia teleutospores and Thecaphora basidiospores, occasionally Juglans, Castanea, Fraxinus and Olea (Stevenson, 1985; Stevenson and Moore, 1988; Törnqvist et al., 1989; Janssen, 1994; van der Knaap and van Leeuwen, 1995; Franco-Múgica et al., 1997; Conedera et al., 2004; López-García et al., 1997; Carrión et al., 2001b, 2007; Valero-Garcés et al., 2000a,b, 2004; López-Sáez et al., 2003; González-Sampériz, 2004; López-Sáez and LópezMerino, 2005, Moreno et al., 2009.

- Grazing pressure: Sordariaceae (e.g. Chaetomium, Sordaria, Podospora, Sporormiella) ascospores, Riccia spores, Trichuris eggs, Genisteae, Plantago, Berberis, Urtica dioica (Montserrat, 1992; Carrión, 2001b; Carrión and Navarro, 2002; López-Sáez and López-Merino, 2007).

- Fire events/increased burning: macro/microcharcoal particles, Cistaceae, Erica, Ulex type, Asphodelus albus, Anagallis arvensis type, Pteridium spores, Chaetomium and other carbonicolous fungal spores (Carrión and van Geel, 1999; Carrión, 2002; Carrión et al., 2003, 2007; López-Sáez et al., 1998, 2000; Stevenson, 2000).

\section{Iberian vegetation coping with the Lateglacial-Early Holocene climatic change}

The Iberian Peninsula constitutes a territory where climatic, geological, biogeographical and historical conditions converge to produce environmental heterogeneity, large biological diversity, and a remarkable species and ecosystem richness (Rey Benayas and Scheiner, 2002). The flora of the Iberian Peninsula and Balearic Islands is located in two biogeographical/climatic regions: Eurosiberian and Mediterranean. The first includes the territories located to the north and the northwest of the Peninsula, with wet, cool climate and without marked summer drought, whereas the rest of the peninsular territory, including the Balearic Islands, enters within the domain of the Mediterranean region, with warm, dry summers and relatively cool, wet winters (Peinado Lorca and Rivas-Martínez, 1987).

A monographic description of the variability of sequences in the whole Peninsula is beyond the scope of this paper. Rather, given the high diversity of the ecosystems, our synthesis deploys a classification of fast-responding records to increasing temperatures giving place to expected vegetation dynamics (Expected Sequences) versus those cases less sensitive to climate change (Unexpected Sequences). We will also include within "unexpected" those situations which, despite existent vegetation reactivity, the dynamics observed do not correspond with the most frequent cases. Changes in rainfall patterns during the Lateglacial and Early Holocene periods were produced at different spatial scales and there is no agreement about their potential synchronicity in the peninsula (e.g. Valero-Garcés et al., 2004).

\subsection{Expected sequences: climate-sensitive vegetation changes}

It is expected that during the Lateglacial and Early Holocene, a counterpart of the high-latitude European protocratic and mesocractic phases (Birks, 1986; Brewer et al., 2002) is found in the Iberian Peninsula. On a global scale, during the Last Glacial Maximum (LGM), temperature and precipitation reached minimum values, and north European landscapes were dominated by treeless tundra and prairiesteppe. Refugia for forest vegetation occurred in southern Europe (Finlayson and Carrión, 2007; Leroy and Arpe, 2007; Medail and Diadema, 2009) and particular regions of central Europe (Willis and van 
Andel, 2004), perhaps with cryptic refugia (areas of sheltered topography that provided suitable stable microclimates) in northern latitudes (Bhagwat and Willis, 2008; Provan and Bennett, 2008; Stewart and Dalén, 2008). But by the Lateglacial period, Pinus, Juniperus, and Betula, and then Quercus spread northward from southern European localities. The Younger Dryas cold period interrupted this trend for several centuries between ca. 12,650 and 11,500 cal. yr BP. The onset of the Holocene witnessed range expansions of angiosperm trees (Corylus, Alnus, Fraxinus, Ulmus, Acer, Abies, Fagus, and Quercus). Approximately 6000 years ago northern hemisphere ice pulled back to near modern limits, and most European forests reached their maximum extent. According to this picture, as discussed by Carrión (2001a), pollen diagrams from the southern European peninsulas show most of the following characteristics: (i) increases of Quercus pollen since Lateglacial period, with the earliest occurrences in southernmost and coastal regions and the thermomediterranean belt, (ii) evidence for the Younger Dryas cold period in the form of expansion of xerophytes, and (iii) mesic tree forest maxima during the first Holocene millennia. Vegetation sequences near the current mountain treeline were characterized by open Pinus and Juniperus woodlands (Peñalba, 1994). Divergences from this basic pattern have been often considered as result of site constraints or regional climate heterogeneity (e.g. Ramil-Rego et al., 1998; Muñoz-Sobrino et al., 2001).
Abundant examples exist of sequences corresponding to this dynamic model, especially in the Eurosiberian Region and areas under the Atlantic influence; Galicia, Portugal and south-western Spain (Figs. 1 and 2). These include the pollen records of Lago Enol in the north (López-Merino, 2009), Tramacastilla and El Portalet in the Pyrenees (Montserrat, 1992; González-Sampériz et al., 2006), Banyoles in the northeast (Pérez-Obiol and Julià, 1994) (Fig. 2), Pozo do Carballal (Muñoz-Sobrino et al., 1997) and Sanabria (Allen et al., 1996) in the northwest (Figs. 2-3), Lagoa Marinho in Sierra de Geres of northern Portugal (Ramil-Rego et al., 1993), Lagoa Comprida (van den Brink and Janssen, 1985) and Charco da Candieira in Serra da Estrela, central Portugal (van der Knaap and van Leeuwen, 1995) (Fig. 4), and Padul in the southeast, northwest of the Sierra Nevada (Pons and Reille, 1988) (Fig. 2). The situation in the island of Ibiza, with the pollen sequences of Prat de Vila and Prats de ses Monges (Yll et al., 2009), fits into this expected pattern. Among the charcoal records, the most complete are probably Mougás in the Eurosiberian region (Carrión-Marco, 2003), and Buraca Grande, Cabeço do Porto Marinho, Cova de les Cendres and Tossal de la Roca in the Mediterranean Region (Fig. 5). Other macroremains (leaves, twigs, trunks, etc.) provide information on the species involved. Thus, the Eurosiberian region is noted for the abundance of Quercus robur, $Q$. petraea, Q. ilex, Salix atrocinerea, Corylus avellana, Fagus sylvatica,

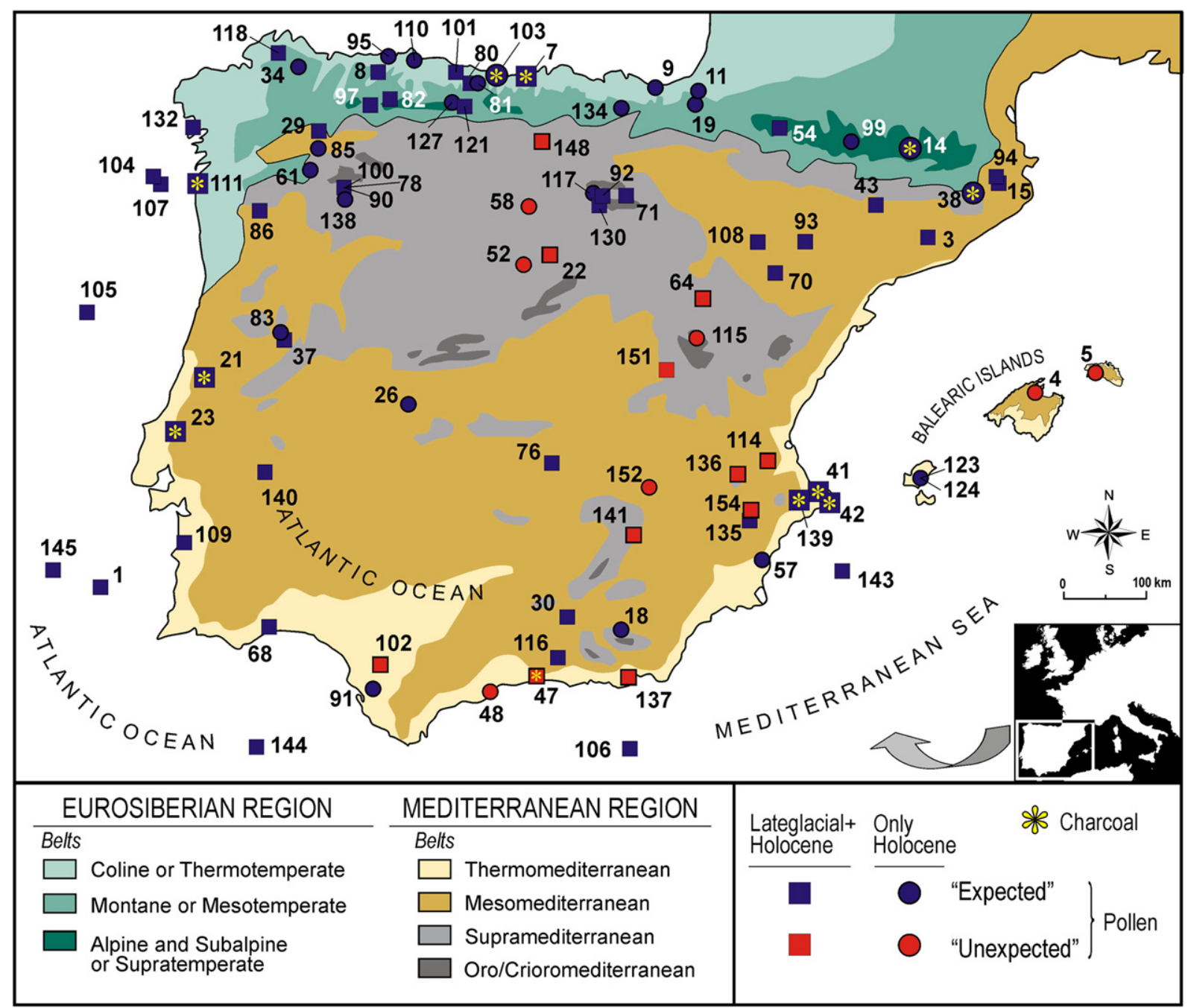

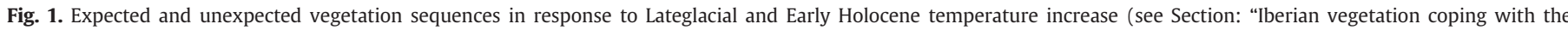

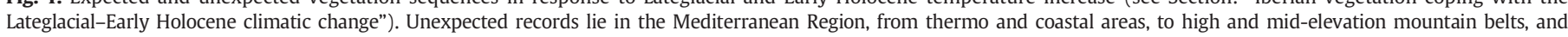

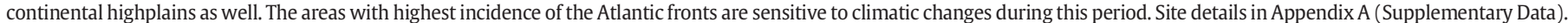




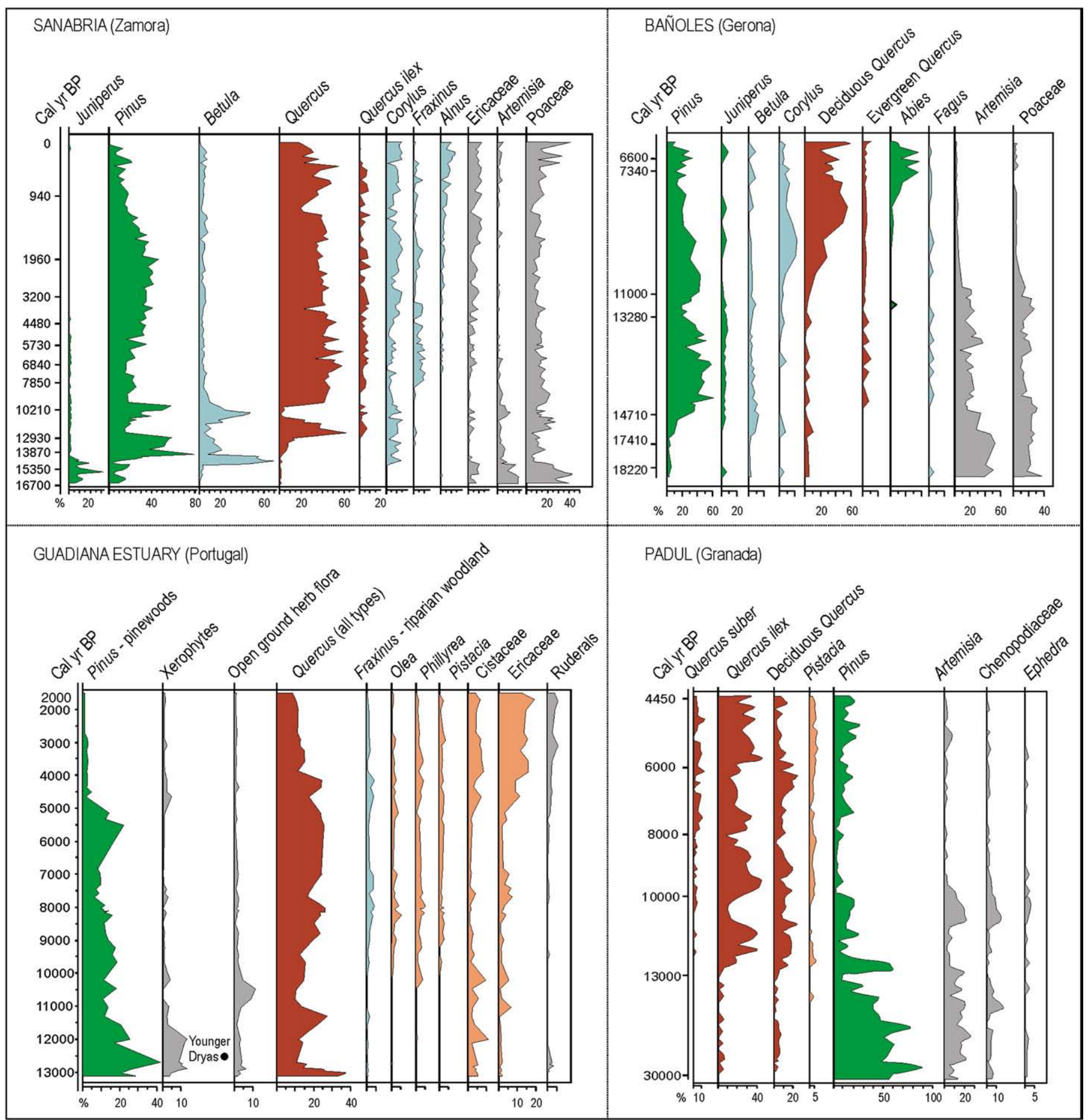

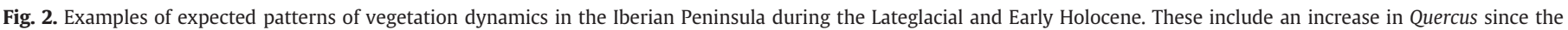

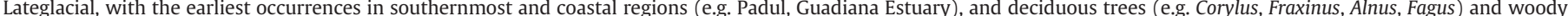

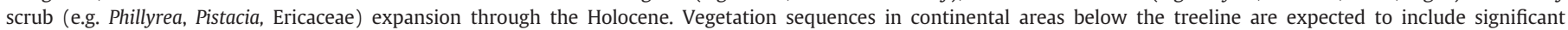
contribution of Pinus to the dominant oaklands, like in Sanabria. The Younger Dryas is characterized by the expansion of xerophytes.

Abies alba, Pinus sylvestris, P. nigra, Acer pseudoplatanus, Arbutus unedo, and Alnus glutinosa, among others (García-Antón et al., 2006; García-Amorena et al., 2007, 2008). For the Mediterranean region, there are macroremains of Quercus ilex-rotundifolia, Q. pyrenaica, Q. faginea, Pinus halepensis, P. pinaster, P. nigra, P. pinea, Olea europaea, and Populus nigra, among others (García-Amorena et al., 2008). Finally, marine sediment pollen records such as MD99-2331 (Naughton et al., 2007), MD03-2697 (Naughton et al., 2007), SU-8118 (Parra, 1994), MD95-2042 (Sánchez-Goñi et al., 2002), SU-8113 (Parra,
1994), MD95-2043 (Sánchez-Goñi et al., 2002), and SU8103 (Parra, 1994) confirm that these overall trends.

Variations within the "expected" can be explained by the topographical context of the different sites. For instance, continentality, altitude and aridity may have circumstancially favoured Pinus in opposition to Quercus. Thus, the existence of Pinus woodlands during the Lateglacial and Early Holocene as a consequence of the orographic influence is a widespread feature in several of the Iberian mountain pollen records, such as Lago Enol (López-Merino, 2009), Comeya (Ruíz-Zapata et al., 


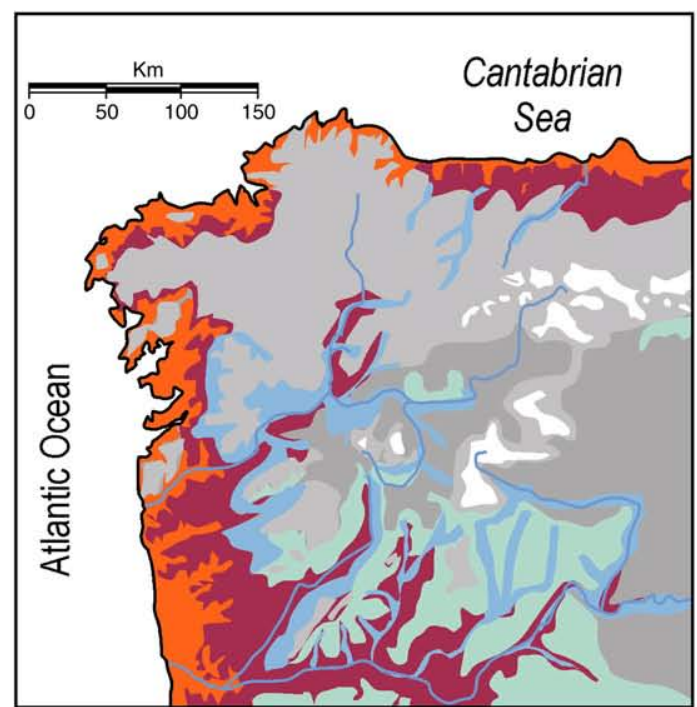

$20000 / 15000$ cal BP

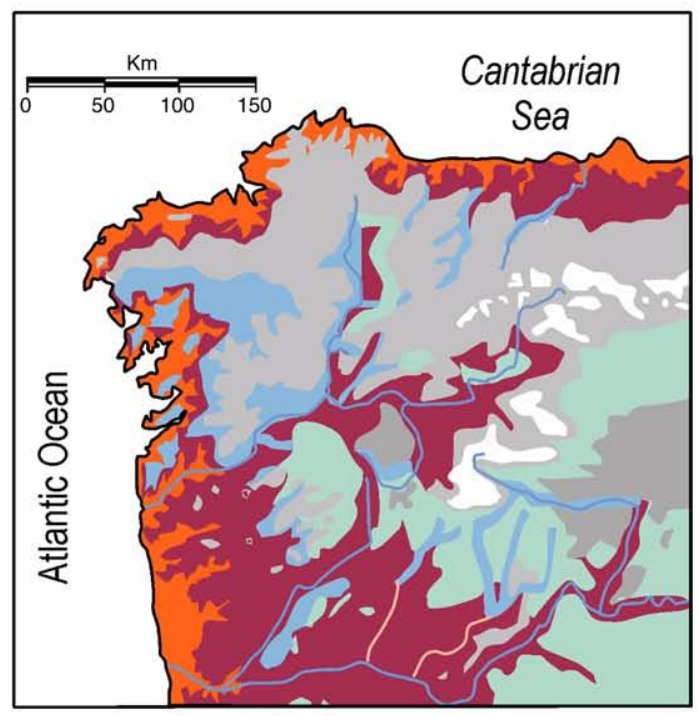

$12000 / 11000 \mathrm{cal} \mathrm{BP}$

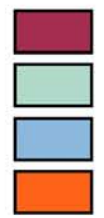

Deciduous woods (Quercus)

Pinus woodland

Boreal deciduous woods (Betula, Alnus, Salix)

Mesothermophilous woods deciduous/evergreen

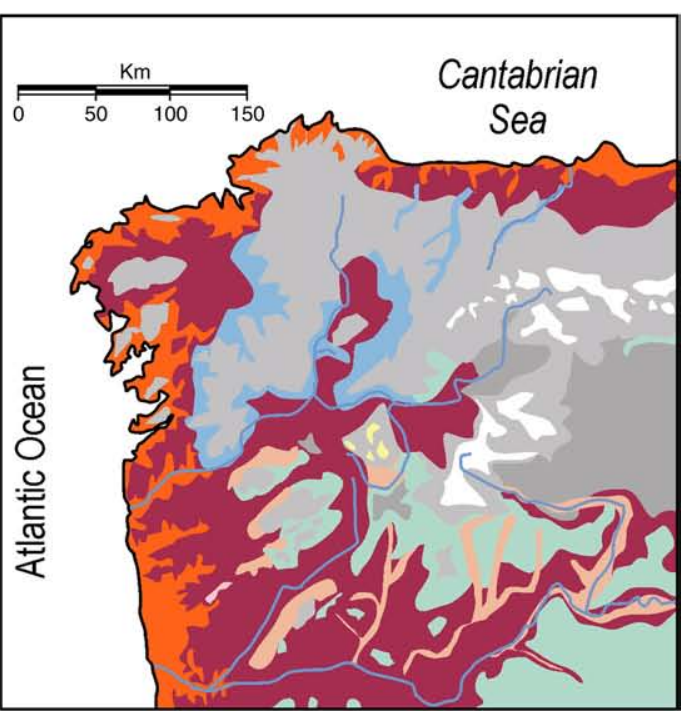

$15000 / 12000$ cal BP

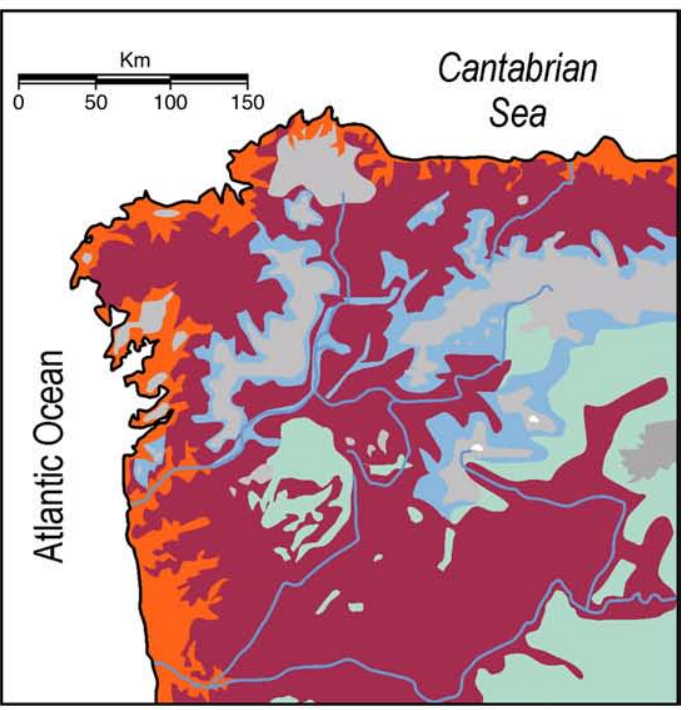

$11000 / 8000$ cal BP

Grass and alpine dwarf shrubs

Steppe forbs/shrubs

Glacio-nival belt

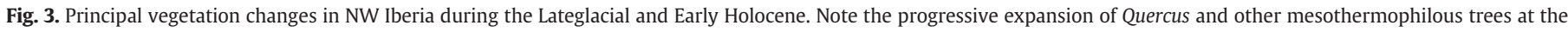

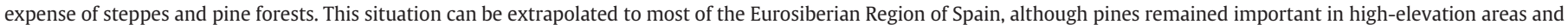
others of Mediterranean influence or extreme continentality. Redrawn from Muñoz-Sobrino et al. (2007).

2001), Polvoredo (García-Rovés, 2007), San Isidro (Fombella Blanco et al., 2003) and Lago Mayor del Valle (Allen et al., 1996) in the Cantabrian range; Lagoa Lucenza (Muñoz-Sobrino et al., 2001) in Galicia, El Portalet (González-Sampériz et al., 2006) in the Pyrenees, and Llauset (Montserrat and Vilaplana, 1987), Quintanar de la Sierra (Peñalba et al., 1997; Ruíz-Zapata et al., 2002), Hoyos de Iregua (Gil-García et al., 2002; GilGarcía and Ruiz-Zapata, 2004) and Las Pardillas (Sánchez-Goñi and Hannon, 1999) in the Iberian range (Fig. 1). Similarly, typical summer drought conditions like in the Central Ebro depression at sites like Hoya del Castillo and Laguna Guállar (Zaragoza) may have contributed to the occurrence of Pinus woodlands during the Lateglacial (Davis and Stevenson, 2007). In southern Iberia, Pinus prevailed during the Early
Holocene in the high-elevation Sierra de Baza (Carrión et al., 2007), the dry lowlands of Elx (Burjachs and Riera, 1995) and the Guadiana Estuary in the southwest (Fletcher et al., 2007) (Fig. 2). The Atlantic coast pollen record 8057B confirms this pattern (Hooghiemstra et al., 1992).

As for the pine distribution in these records, Pinus nigra and Pinus sylvestris would have been widespread at high altitudes (Rubiales et al., 2007; García-Amorena et al., 2007, 2008), while Pinus pinea appeared in the south and thermomediterranean southwest, both in the Pleistocene and Holocene (Badal, 1998, 2006; Carrión et al., 2008), and Pinus halepensis abounded in the east and Ebro Valley (Badal, 2004; Badal et al., 1994, 2008; Allué, 2002; Carrión-Marco, 2005). Pinus uncinata and Pinus sylvestris would have formed the timberline in the Eurosiberian 


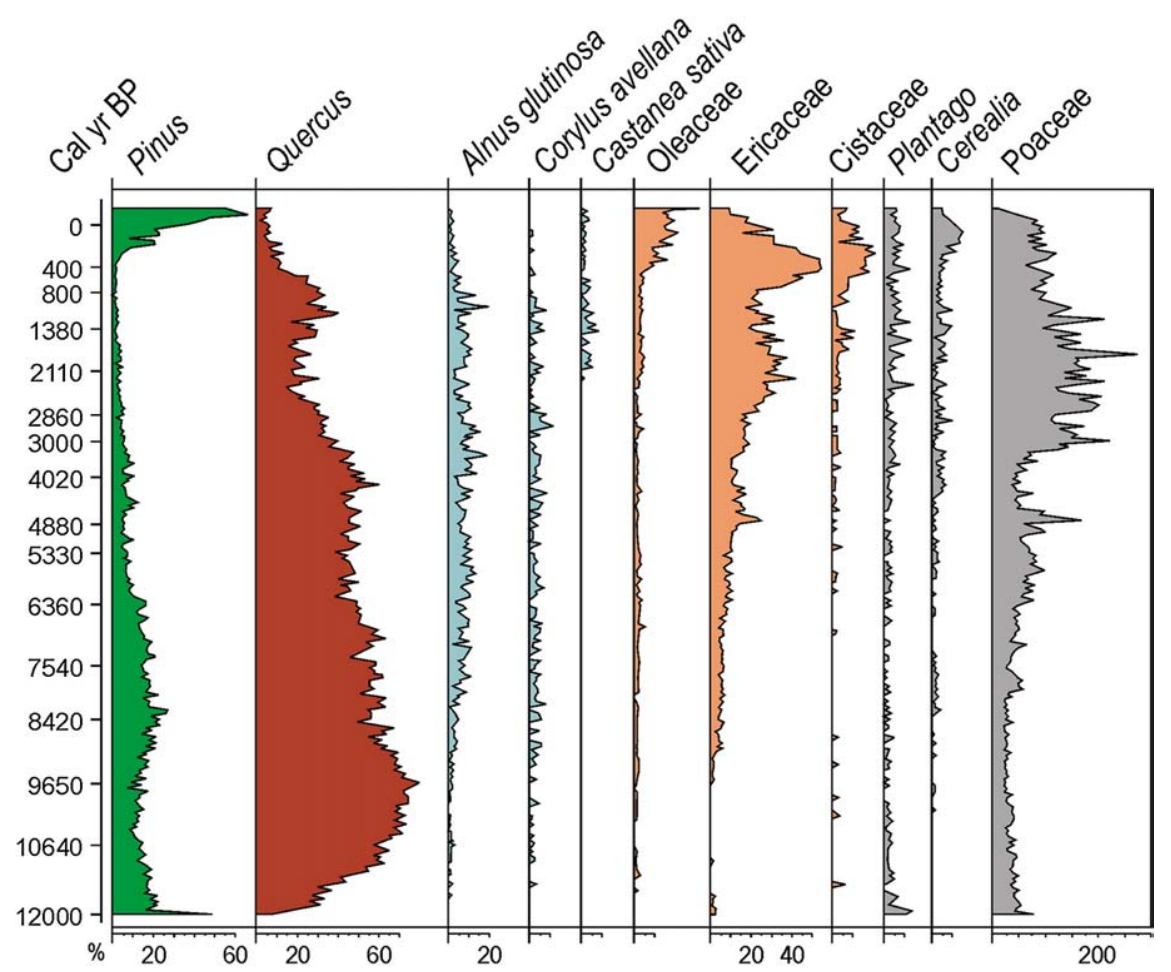

Fig. 4. Holocene vegetational developments in a montane region of the Atlantic Iberia, as shown by the synthetic pollen diagram of Charco da Candieira, central Portugal. Quercus prevails over Pinus in the forest component. The sequence includes indicators (e.g. Cerealia, Plantago, Castanea, among others) of anthropogenic disturbance ever since the Middle Holocene. Human activities are therefore associated with progressive opening of the landscape and increase of Cistaceae-Ericaceae scrub. Redrawn from van der Knaap and van Leeuwen (1997).

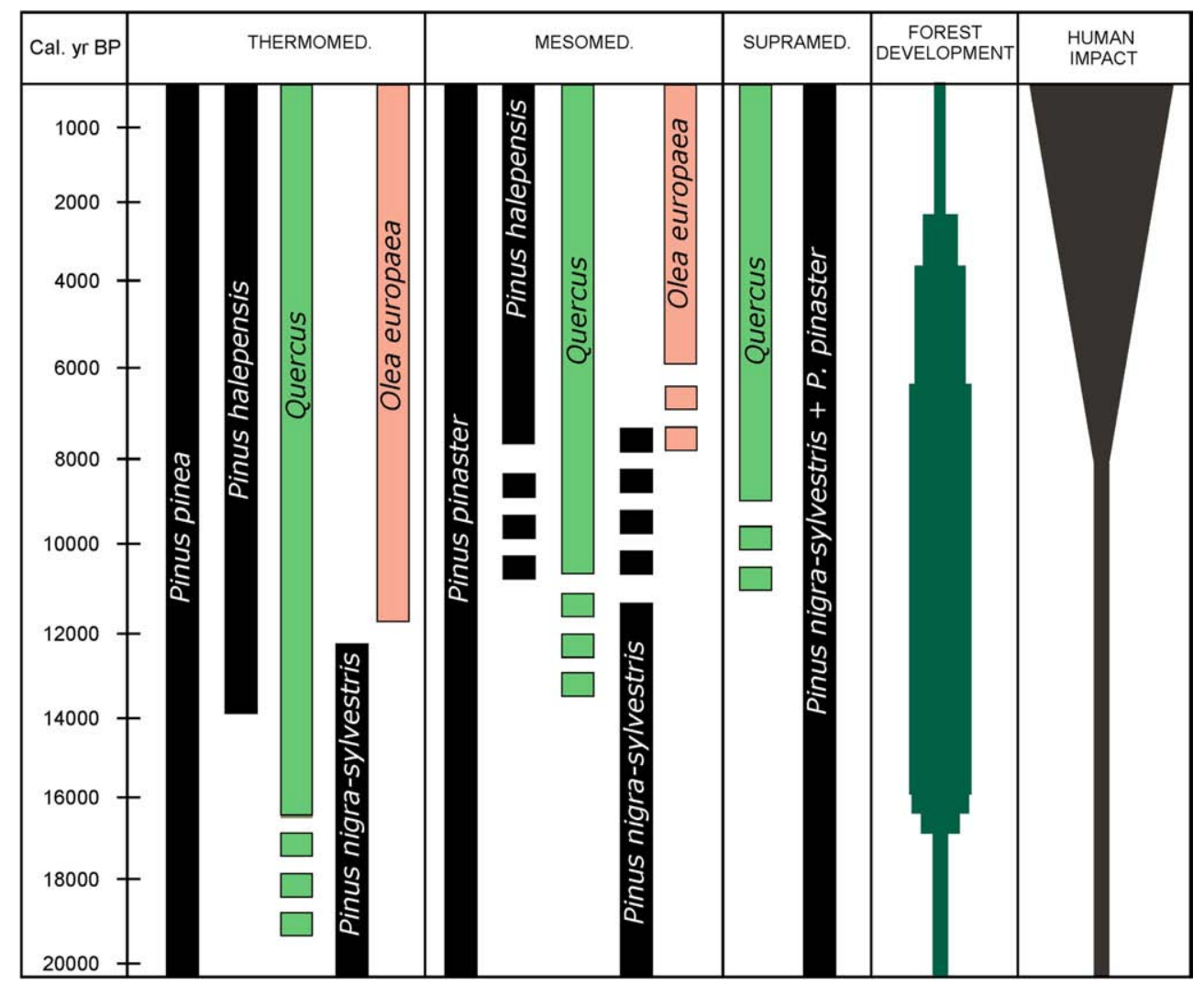

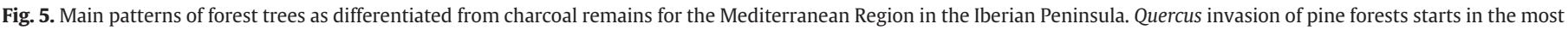

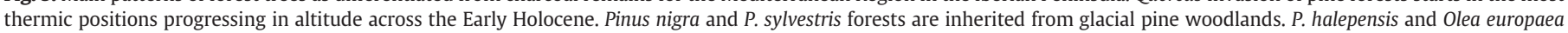
develop with the matorralization of ecosystems in the Mediterranean region. Human impacts are noticed from the Neolithic onwards. 
region (Heinz, 1991; Uzquiano, 1992a,b; Carrión-Marco, 2005) (Fig. 5). The cluster pine (Pinus pinaster) would have been sporadically dominant in several Iberian mountains (Figueiral, 1995; Figueiral and Terral, 2002; Rubiales et al., 2009), and sometimes forming part of mesophytic forests with deciduous Quercus (Carrión et al., 2000, 2004, 2007; Rubiales et al., 2009). Charcoal analyses suggest that during the Lateglacial, alpine, subalpine, and oromediterranean pine species descended to the thermo and mesomediterranean belts, disappearing progressively throughout the Holocene (Badal et al., 2008) (Fig. 5), although exhibiting an extraordinarily long residence in some areas (Rubiales et al., 2007).

Juniperus sometimes accompanied Pinus and Quercus in the Lateglacial and Early Holocene woodlands of the continental Mediterranean areas. The pollen records of Salines (Giralt et al., 1999) and Salada Mediana (Valero-Garcés et al., 2000a,b) and the charcoal records of Santa Maira (Carrión-Marco, 2005; Aura Tortosa et al., 2006), and La Falguera (Carrión-Marco, 2005) illustrate this case. Other variants of the expected trend include abundance of Betula in humid sites of higher altitudes (Muñoz-Sobrino et al., 2004; LópezMerino, 2009); abundance of Corylus in mesothermic Eurosiberian regions such as the Cantabrian coast (Burjachs and RenaultMiskovsky, 1992; Peñalba, 1994; López-Merino, 2009) (Fig. 3) and Mediterranean riparian areas such as Salada Mediana (Valero-Garcés et al., 2000a,b); and abundance of Olea in the thermomediterranean belt like in Laguna de Medina (Reed et al., 2001). The colonisation by Fagus is generally time-transgressive, starting during the Lateglacial in Sierra de Neila, but delaying its arrival to c. 5700 cal. yr BP or even later in most of northern Spain (Ramil-Rego et al., 2000; LópezMerino et al., 2008; Muñoz-Sobrino et al., 2009).

The Younger Dryas (12,650-11,500 cal. yr BP) of Iberia, as with other regions of the northern hemisphere, does not always have a clear trend in pollen diagrams. However, it can be clearly detected (e.g. increases of Artemisia, Poaceae, Chenopodiaceae, Ephedra, and/or forest depletions) in the Sierra de Geres of northern Portugal (Ramil-Rego et al., 1998), Lagoa Lucenza (Muñoz-Sobrino et al., 2001), Lagoa Lucenza (Santos et al., 2000), Pozo do Carballal (Muñoz-Sobrino et al., 1997), the Cantabrian Lago Mayor del Valle (Allen et al., 1996), Alto de la Espina (López-Merino, 2009), and Lago Enol (López-Merino, 2009), the Iberian Range sites of Hoyos de Iregua (Gil-García et al., 2002), Quintanar de la Sierra (Peñalba et al., 1997; Ruíz-Zapata et al., 2002, 2003a), the Pyrenees (Montserrat, 1992), Cataluña in Banyoles (Pérez-Obiol and Julià, 1994), Sierra de Cabrera in La Roya, Sanabria Marsh (Allen et al., 1996), Sanguijelas and Lleguna (Muñoz-Sobrino et al., 2004), Central Spain in Burgomillodo (Díez et al., 2002), and CC-17 core in Tablas de Daimiel, La Mancha Plain (Dorado-Valiño et al., 2002; Valdeolmillos, 2004); Navarrés (Carrión and Dupré, 1996; Carrión and van Geel, 1999), Villena (Yll et al., 2003), and Tossal de la Roca (Cacho et al., 1995) in eastern Spain, and characteristically Padul in the south (Pons and Reille, 1988). These, among other sites, represent a geographically wide spectrum of sensitive sites to the Younger Dryas cold-dry period.

The response in the rest of the Lateglacial biozones is not so clear, although elements are apparent in some high-resolution sequences. González-Sampériz et al. (2006) were able to correlate the environmental changes observed in El Portalet peat bog in the Pyrenees with several abrupt events observed in northern latitudes (Heinrich events 3 to 1 , Oldest and Older Dryas stades, Intra-Allerød Cold Period, and 8200 cal. yr BP event). The monumental work in Serra da Estrela by van der Knaap and van Leeuwen (1997) is equally detailed at the stratigraphical level, and show palynological changes, especially with Quercus, that fit into the Greenland ice-core curves.

\subsection{Unexpected sequences: absence of change, particular dynamics and threshold responses}

The former, expected, palaeobotanical records are representative of the commonest trends in vegetation development throughout the
Lateglacial and Early Holocene. They support the view that vegetation changes during this interval were generally determined by rapid shifts in the physical properties of the ecosystem. However, more than a few pollen sequences in Mediterranean Spain fail to show persistent trends through time or correlate with the major events described above (Fig. 1). Pollen-stratigraphical changes are episodic and abrupt, that is, they occur on the time scales of decades to centuries. Moreover, some pollen records show millennial-scale complacency to continental-scale climate change. All of these particular trajectories of vegetation dynamics deserve attention, and it is our view they should be conceptualized even when they may appear as less interesting or more inconclusive than the conventional histories directly assignable to climatic changes.

The vegetation sequence of Navarrés shows developments in the southern valleys of the Iberian System from about 30,900 to $3200 \mathrm{cal}$. yr BP (Carrión and van Geel, 1999) (Fig. 6). Pinus forests dominated the glacial landscape and resisted invasion by other species until about 5900 cal. yr BP, even though Quercus and other temperate trees occurred in the region several thousands of years before, as demonstrated by anthracological data (Badal et al., 1994; CarriónMarco, 2005). The variation of macro- and microcharcoal throughout the core suggests that Pinus forests were only replaced by evergreenQuercus scrub after local fire disturbance by the Neolithic populations settled in the vicinity of the study site. Although a prevailing dry climate during the first half of the Holocene may have played some role, our preferred interpretation of this vegetation sequence is that millennial-scale inertia of the established Pinus forests was followed by a threshold response to increased fire frequency and virulence.

Navarrés is not unique as a case of Lateglacial and Early Holocene dominance of pine woodlands. In other pollen sequences, these may extend further in time by reaching the Late Holocene, and this accounts for not only high- and mid-altitude mountain zones, but also coastal territories and interior platforms (Fig. 1). Examples in the vicinity of Navarrés are San Benito (Dupré et al., 1996) and Villena (Yll et al., 2003). In the Verdelpino cave pollen sequence, there is no Quercus colonization during the Magdalenian (Lateglacial) levels, and Quercus only increases after c. 6000 cal. yr BP (López-García, 1977). In El Carrizal, Pinus forests prevailed throughout the Holocene with a minor, subsidiary component of broadleaved forests (Franco-Múgica et al., 2005). In Espinosa de Cerrato, the dominance of Pinus is still more prolonged (Franco-Múgica et al., 2001) (Fig. 7). Similar records can be found in Gallocanta (Burjachs et al., 1996) and Ojos del Tremedal in Montes Universales (Stevenson, 2000). Charcoal analyses show the coexistence of Pinus nigra and $P$. halepensis during the period c. 9900-8200 years BP in the rockshelter of Los Baños (Teruel), and in La Cativera (Tarragona) (Allué, 2002; Badal, 2004).

Other cases are even more divergent from the expected trend. The pollen assemblage in San Rafael shows that temperate trees and Mediterranean woody elements persisted during full glacial times, without any evidence of xerophytization (Pantaleón-Cano et al., 2003). In contrast, Artemisia increases from Lateglacial to Early Holocene. The optima of deciduous trees and Mediterranean scrub (c. 7500-4500 cal. yr BP) occur later than the mesocratic Early Holocene phase of forest development in north-west Europe (Birks, 1986), and there is no record of any Lateglacial expansion of Quercus. San Rafael, therefore, shows out-of-phase relationships in trends of meso- and xerophytic developments. Moreover, within the semi-arid southeastern province, the patterns and timing of Holocene vegetation stages differ in San Rafael, and the nearby Antas and Roquetas de Mar (Pantaleón-Cano, 1997; Pantaleón-Cano et al., 2003), Elx (Burjachs and Riera, 1995), Salines (Burjachs et al., 1997), Gádor (Carrión et al., 2003), Caldereros (Fuentes et al., 2005), Ubeda and Baeza (Fuentes et al., 2007), Carihuela (Fernández et al., 2007), and Baza (Carrión et al., 2007) (Fig. 1). The difficulties with the correlation of sequence events increase notably if we integrate charcoal records (Rodríguez-Ariza, 1992, 2000). 


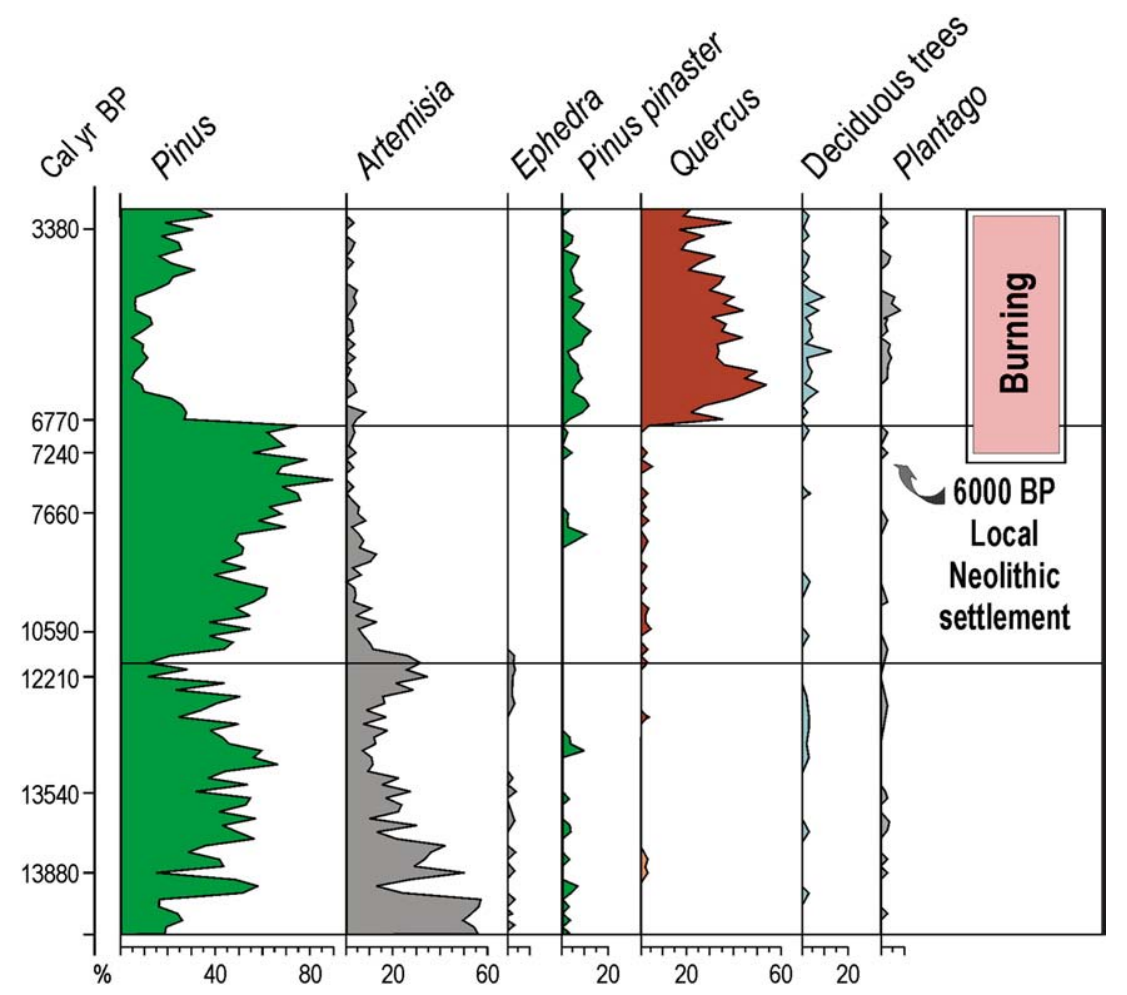

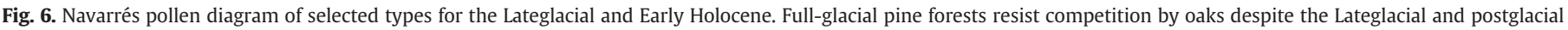

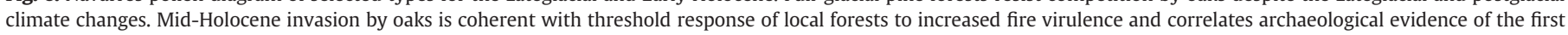
Neolithic settlements in the vicinity of the study site. Redrawn from Carrión and van Geel (1999).

In the Sierra de Segura, the Pleistocene-Holocene pollen record of Siles also exhibits its own distinctiveness (Carrión, 2002). There is a first increase of Quercus from c. 12,000 to 10,500 cal. yr BP, then it drops while Pinus nigra and $P$. pinaster increase and domain the landscape until c. 7420 cal. yr BP, when deciduous Quercus invade abruptly the supramediterranean belt (Fig. 13). Another atypical

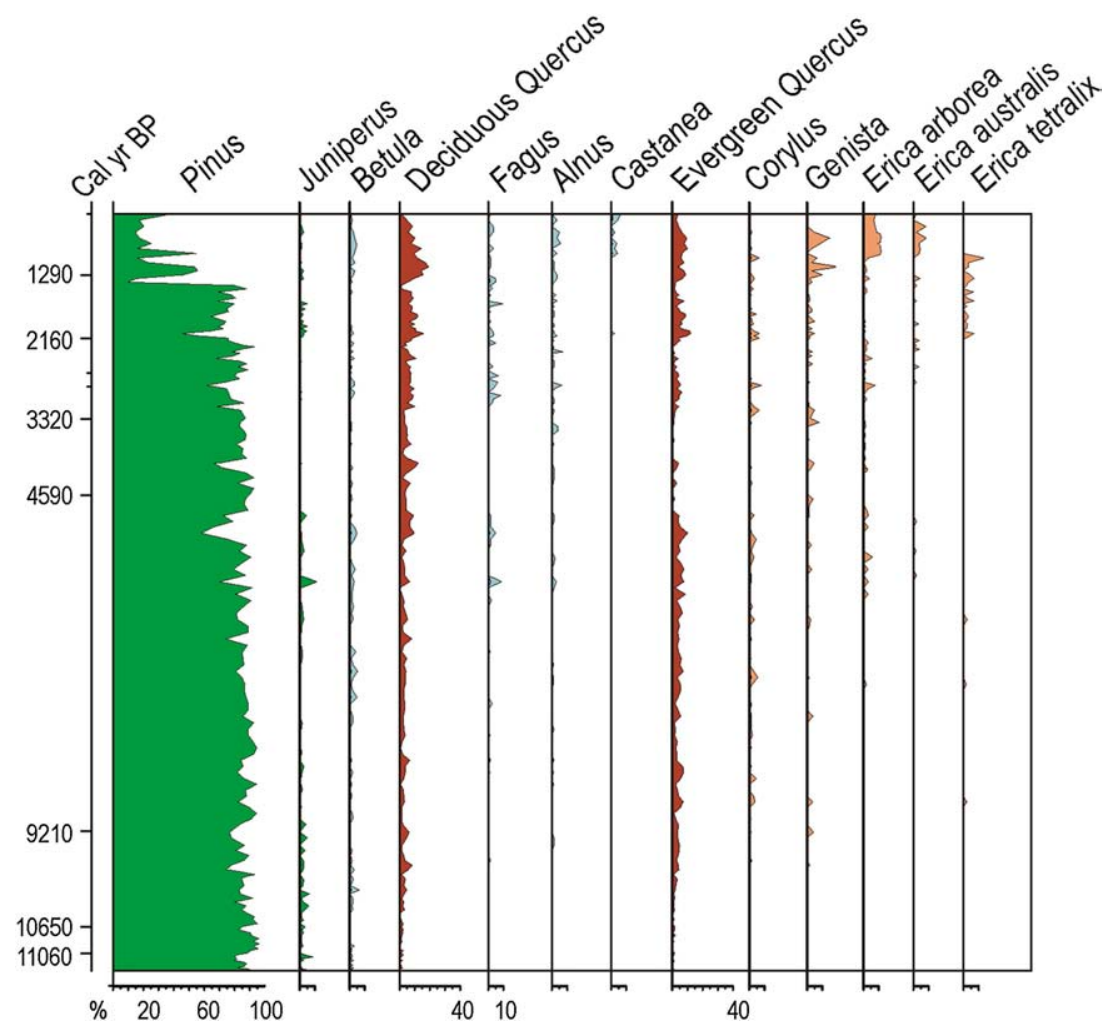

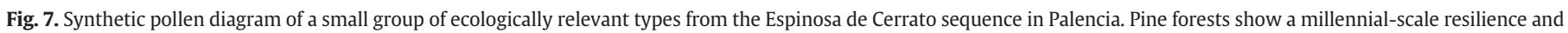
prevail as main vegetation type at about 800-900 m a.s.l. in north-central Spain. Redrawn from Franco-Múgica et al. (2001). 
vegetation history is seen in Bajondillo, southern Mediterranean coast. Pinus, Quercus ilex, Betula and Abies expand during the LGM and Lateglacial, while the onset of the Holocene is characterized by a partial replacement of these taxa by Alnus, Corylus, Fraxinus, Ilex, Ulmus, and Quercus pyrenaica type. The most important Quercus developments only occur after c. 7500 cal. yr BP (Cortés Sánchez et al., 2008). The pollen spectra from Bajondillo, however, might be strongly influenced by the vicinity of the southeastern Baetic mountains. In charcoal analyses of similarly thermic areas of Mediterranean Iberia, tree species such as Abies, Corylus and Betula have so far not been identified (Rodríguez-Ariza, 1992, 2000; Badal, 1998). Although they do not go back to the very onset of the Holocene, the Early-Late Holocene pollen sequences of Algendar in Menorca (Yll et al., 1997) (Fig. 8) and Albufera de Alcudia in Mallorca (Burjachs et al., 1994) show very particular vegetation dynamics since about 7800 cal. yr BP, with Juniperus, Pinus, Buxus and Corylus as main protagonists.

Most of the cases described as "unexpected" lie in the Mediterranean Region, although in very different physiographic contexts (Fig. 1). As in the present, landscape heterogeneity could explain the occurrence of different vegetation types and moderate time lags in the response to climatic changes. When a primary climatic control is provided though, there should be certain overlap in the timing as well as in the palaeoclimatic significance of major events. Is it therefore possible that Early Holocene vegetation developments were influenced by the composition and structure of the former plant communities? Could the cases of early-Holocene prevalence of pines be associated to areas where well-structured pine forests featured in the Lateglacial and/or full-glacial landscapes? In general, pines show great phenotypic plasticity and resistance to invasion due to a set of ecophysiological characteristics that make them competitive in stressful environments (Rubiales et al., 2009). Facilitation is another plausible factor of species replacement, and there are case studies with Quercus versus Pinus (Gómez-Aparicio et al., 2005; Gómez-Aparicio and Canham, 2008). The climatic factor cannot be neglected, in any case, because the regions under the influence of Atlantic fronts show expected vegetation histories (Fig. 1). Palaeoecologically, what is clearly different between the Eurosiberian and Mediterranean region of Iberia is the full-glacial vegetation, with more mesothermophilous trees, and a greater extension of pine woodlands in the latter than the former (Carrión et al., 2008).

Phytogeographical hotspots of the Iberian Peninsula and Balearic Islands, as postulated by the cohesion of palaeobotanical, phylogeographical, and neoecological studies, all lie in the Mediterranean Region (Medail and Diadema, 2009). So the glacial situation would be more complex in the Mediterranean, affecting not only the plants (Jiménez et al., 2004; Magri et al., 2006; Leroy and Arpe, 2007; López de Heredia et al., 2007), but also the fauna (Gómez and Lunt, 2007; Finlayson and Carrión, 2007; Stewart and Dalén, 2008), and yet not only at the population but also to the community and ecosystem levels (Arroyo et al., 2008). In this situation, subtle differences in initial conditions during the full-glacial could have affected the outcome of post-glacial events. In other words, due to the complex distribution and composition of forests during the glacial phases, a simple postglacial picture of vegetation dynamics cannot be expected.

\section{Humans as agents of disturbance (and more "unexpected pathways")}

Climate has, doubtless, exerted an important influence on Holocene vegetation sequences of the Iberian Peninsula, above all into the Eurosiberian Region (Fig. 1). Palaeoecological records of the Atlantic territories exhibit directional changes suitable to correlation with the Greenland isotopic records (Mayewski et al., 2004). Thus, during the Early Holocene up to $7800 \mathrm{cal}$. yr BP, pollen sequences depict at least two episodes of xerophytization paralleling the GH-11.2 and GH-8.2 events (Muñoz-Sobrino et al., 2007). The 8.2 ka cold event

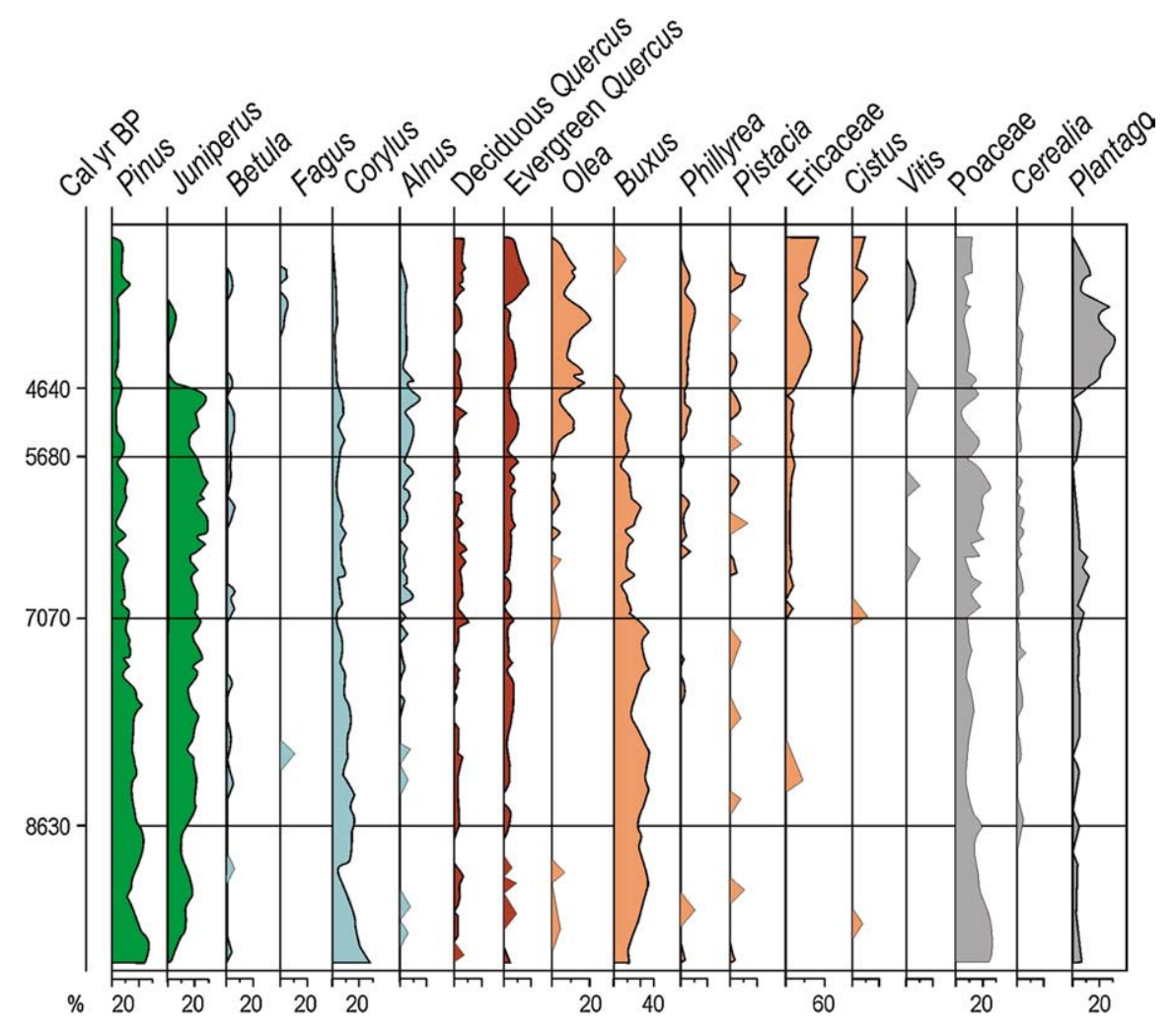

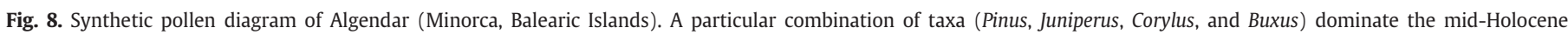
assemblages, while evergreen Quercus rises in the phase of more intense human activities, accompanied by Olea, Plantago, and Vitis. Redrawn from Yll et al. (1997). 
is also discernible in the Central Ebro River Basin where its magnitude provoked the hunter-gatherer groups to migrate to regions with more favourable conditions (González-Sampériz et al., 2009). The Cañada de la Cruz pollen record shows that the ecotones between high-elevation pine forests and xerophytic grassland-scrub have changed in altitude at least five times over the last 10,000 years, and do appear to be sensitive to temperature change, although this must be strongly related with wind exposure, continentality, and average climate xericity (Carrión et al., 2001a). These changes are synchronous with periods of abrupt oscillations and rapid transitions in the climates of north Africa and the Sahel (Gasse, 2000), and the North Atlantic region (Lauritzen, 1996). Aridification phases inferred from pollen ratios in Mediterranean Iberia have been established at c. 8400-7600, 53004200, 4300-3400, 2850-1730, and 1300-750 cal. yr BP (Jalut et al., 2000), in correlation with arid intervals at Tigalmamine, north Africa (Lamb et al., 1995). In addition, it has been shown in a number of sequences from southern Spain that the period from c. 7500-5200 cal. yr BP represents the mesophytic optimum and the period of lowest fire activity (Burjachs and Riera, 1995, Pantaleón-Cano et al. 1996, Carrión, 2002; Carrión et al., 2003, 2007). In contrast, the sites of Padul (Pons and Reille, 1988), and Elx and Salines (Burjachs et al., 1997) show
early-Holocene (c. 11,500-8500 cal. yr BP) mesophyte maxima. Similar asymmetries are acknowledged in northern Iberia, from Galicia to the Cantabrian region (Muñoz-Sobrino et al., 2005), the Pyrenees and northeastern Spain (González-Sampériz et al., 2005, 2006). For instance, pollen data from NW Spain (Allen et al., 1996; Muñoz-Sobrino et al., 2001, 2004) depict a woodland expansion between 8000 and $2000 \mathrm{cal}$. yr BP, while the Cantabrian sequences show two forest maxima at $8000-7500$ and from 5000 cal. yr BP onwards, separated by a phase of more open landscapes (MuñozSobrino et al., 2005).

Regardless of the bioclimatic region, it appears, however, that the patterns of vegetation change reach maximum complexity between the Mid- and Late Holocene, and although some trends can be wellestablished for several territories, the timing of forest declines and expansions are spatially uneven and cannot be solely explained by current differences in physical setting (Carrión et al., 2000; Gil-Romera et al., 2009). Among the factors involved we need to consider the role of anthropogenic disturbance, which no doubt was spatially heterogeneous. Burning, pastoralism, and ploughing by agrarian and metallurgic societies, for instance, may have been historically decisive and site-specific. It is perhaps significant that this heterogeneity of

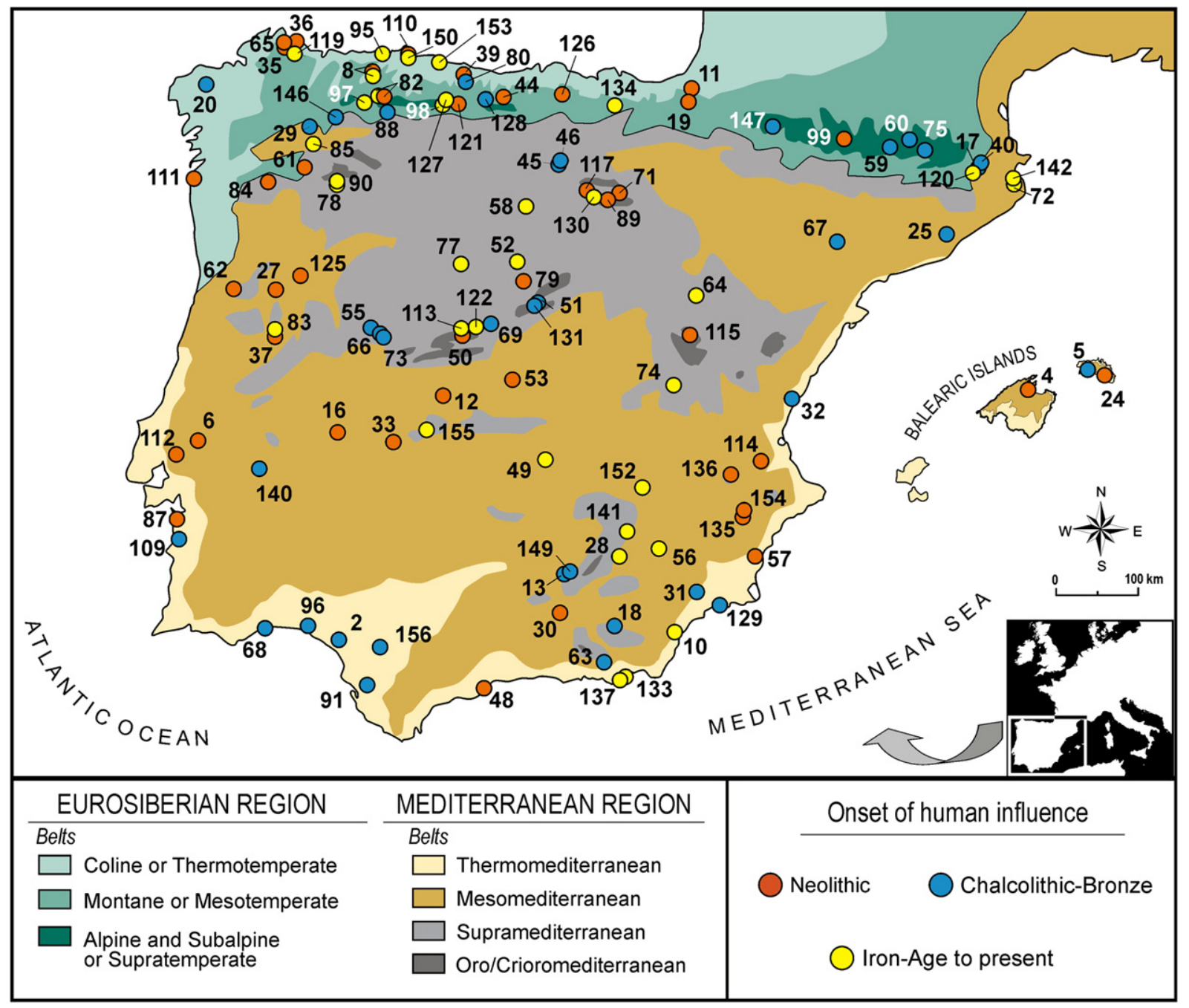

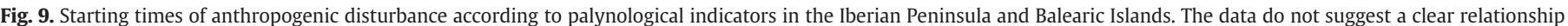

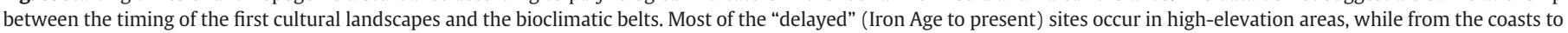

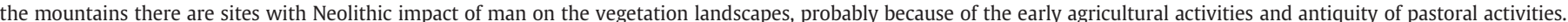

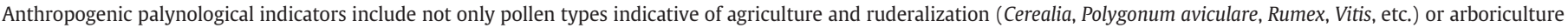

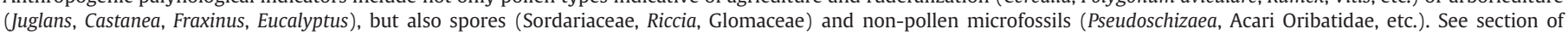
"Palaeoecological indicators" for further detail. Site details in Appendix A (Supplementary Information). 
environmental change increases from Mid to Late Holocene, which strongly suggests that human activities have been of crucial importance to shape current landscapes.

Fig. 9 shows the Holocene pollen sites in which anthropogenic disturbance has been identified through palynological indicators and contextualized through the archaeological record. The geography of impacted sites is puzzling for any period considered. Many outstanding pollen sites show starting times of anthropogenic disturbance falling into the Neolithic period, such as Villena (Yll et al., 2003), Navarrés (Carrión and van Geel, 1999), and San Benito (Dupré et al., 1996) in the east; Puerto de los Tornos and Atxuri (Peñalba, 1994), Mougás (Gómez-Orellana et al., 1998), Monte Areo and Alto de la Espina (López-Merino, 2009), Comeya (Jiménez Sánchez et al., 2003), Hoyos de Iregua (Gil-García et al., 2002) in the north; Azután (Bueno et al., 2002), Barruecos (López-Sáez et al., 2005) and Dehesa Río Fortes (López-Sáez, 2002) in central Iberia; Cerro de la Horca (López-Sáez et al., 2007), Prazo (López-Sáez et al., 2007), Muge Valley (van der Schriek et al., 2007), and Charco da Candieira (van der Knaap and van Leeuwen, 1994, 1995, 1997) in Portugal and the southwest; Bajondillo (Cortés Sánchez et al., 2008), and Carihuela (Fernández et al., 2007) in southern Spain; Cala'n Porter (Yll et al., 1997) (Fig. 8) and Albufera de Alcudia (Burjachs et al., 1994) in the Balearic Islands. Anthracological and palaeocarpological information confirms this early influence of man for the same regions (Uzquiano, 1992a; Figueiral, 1993; Buxó, 1997; Rodríguez-Ariza, 1992, 1995; Zapata, 2002; Zapata et al., 2004; López-García et al., 2003; Carrión-Marco, 2005; Peña-Chocarro et al., 2005; Piqué, 2005; Badal et al., 2008). Charcoal of evergreen Quercus, present in north Atlantic Iberia, from Neolithic to Bronze Age levels of archaeological sites, has been interpreted as the result of human action (Zapata, 2002). It must be emphasized though that the degree of landscape change that was clearly caused by human activities during the early Neolithic is low, difficult to detect, and not free from controversy (Carrión et al., 2007; López-Merino, 2009).
The establishment of "cultural landscapes" during the expansion of metallurgical communities (Fig. 9) is clearly depicted in pollen diagrams. Thus, during the Chalcolithic and Bronze-Age cultural periods, many sites in the Iberian Peninsula show vegetation changes more or less correlated with the timing of disturbances by humans. Several examples are Can Roqueta (Burjachs and Expósito, 2007), Lago Enol (López-Merino, 2009, Pozo do Carballal (Muñoz-Sobrino et al., 2007), San Isidro (Fombella Blanco et al., 2003), and Tramacastilla (Montserrat, 1992) in the north; Carril de Caldereros (Fuentes et al., 2005), and Cova 120 (Burjachs, 1988) in eastern Spain; Rascafría (Ruíz-Zapata et al., 2006), El Portalón (Ruíz-Zapata et al., 2003b), and Covatilla (Atienza, 1995) in central Spain; Melides (Santos et al., 2002) in Portugal; Acebrón (Stevenson and Harrison, 1992) (Fig. 10), Las Madres (Stevenson, 1985), Medina (Reed et al., 2001), Baza (Carrión et al., 2007), Gádor (Carrión et al., 2003), Baeza and Úbeda (Fuentes et al., 2007) in southern Spain, and Algendar in Minorca (Yll et al., 1997) (Fig. 11). Again, this thesis is supported by the anthracological and palaeocarpological information related with archaeological surveys (Grau, 1990; Rodríguez-Ariza and Vernet, 1991; Rodríguez-Ariza, 1995, 2000; Buxó, 1997; Cámalich and Martín, 1999; Castro et al., 1999; Carrión-Marco, 2004, 2005; García and Grau, 2005; Allué et al., 2006; Ros Sala, 2008).

Many of the former sites continue to be affected by anthropogenic degradation during Iron Age times, the Romanization and episodes of the last centuries. However, other pollen sites only show anthropogenic indicators after Roman times, or even only during the last centuries (Fig. 9). Alteration usually includes human-set fires often combined with overgrazing, opening of the landscapes, spread of grasslands, thorny scrub and junipers in altitude, depletion of mesophytes, increases of heaths in the Eurosiberian Region, and garrigas in the Mediterranean Region, loss of arboreal diversity and increase of heliophytic herbs. Sites like El Sabinar (Carrión et al., 2004), Siles (Carrión, 2002), Daimiel (Gil-García et al., 2007), El Carrizal (Franco-

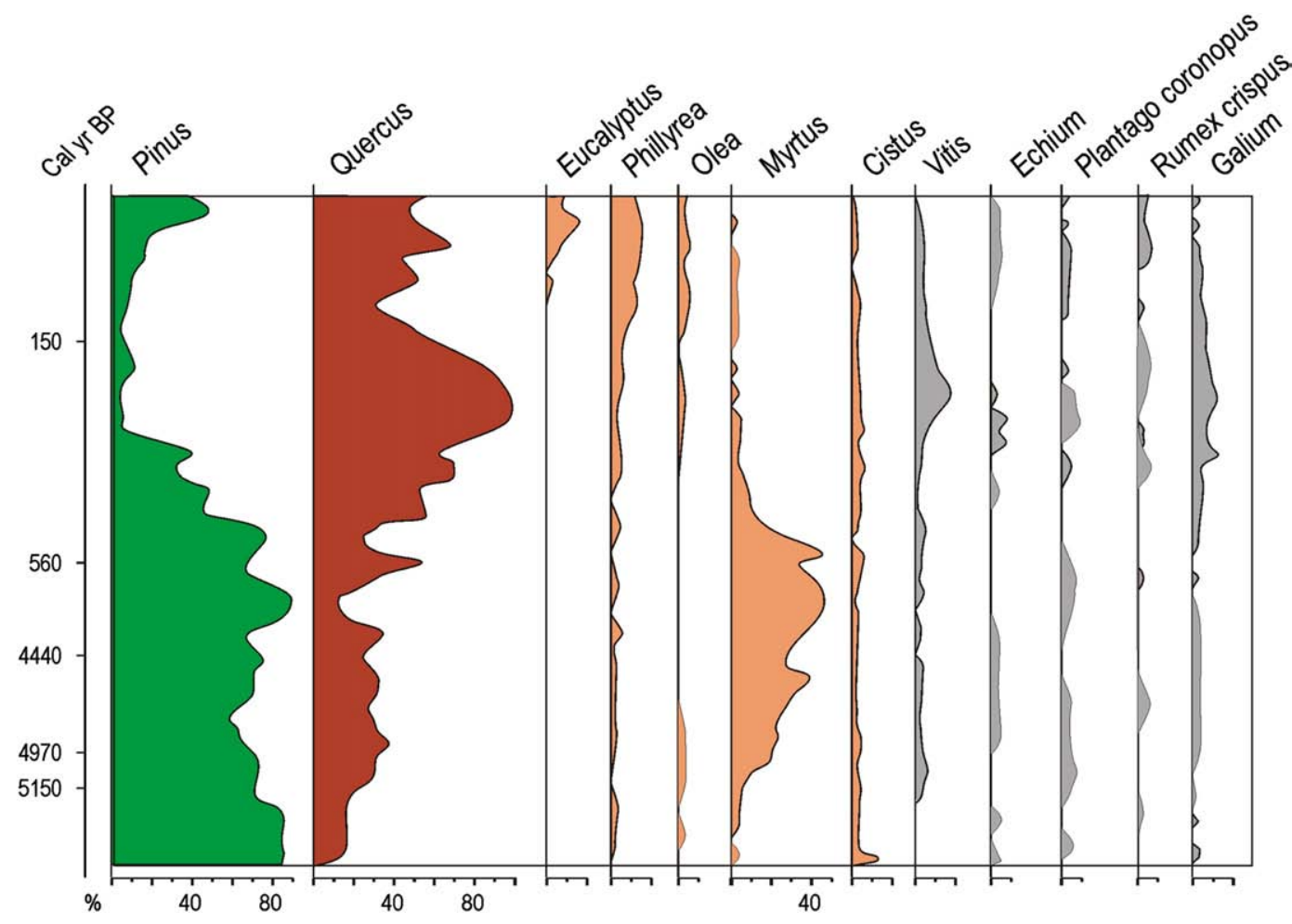

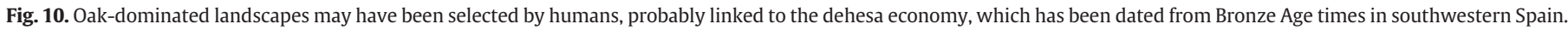

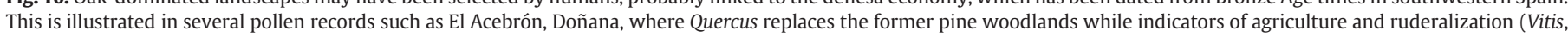
Echium, Plantago, Rumex, Galium) are present from c. 4510 cal. BP. Redrawn from Stevenson and Harrison (1992). 


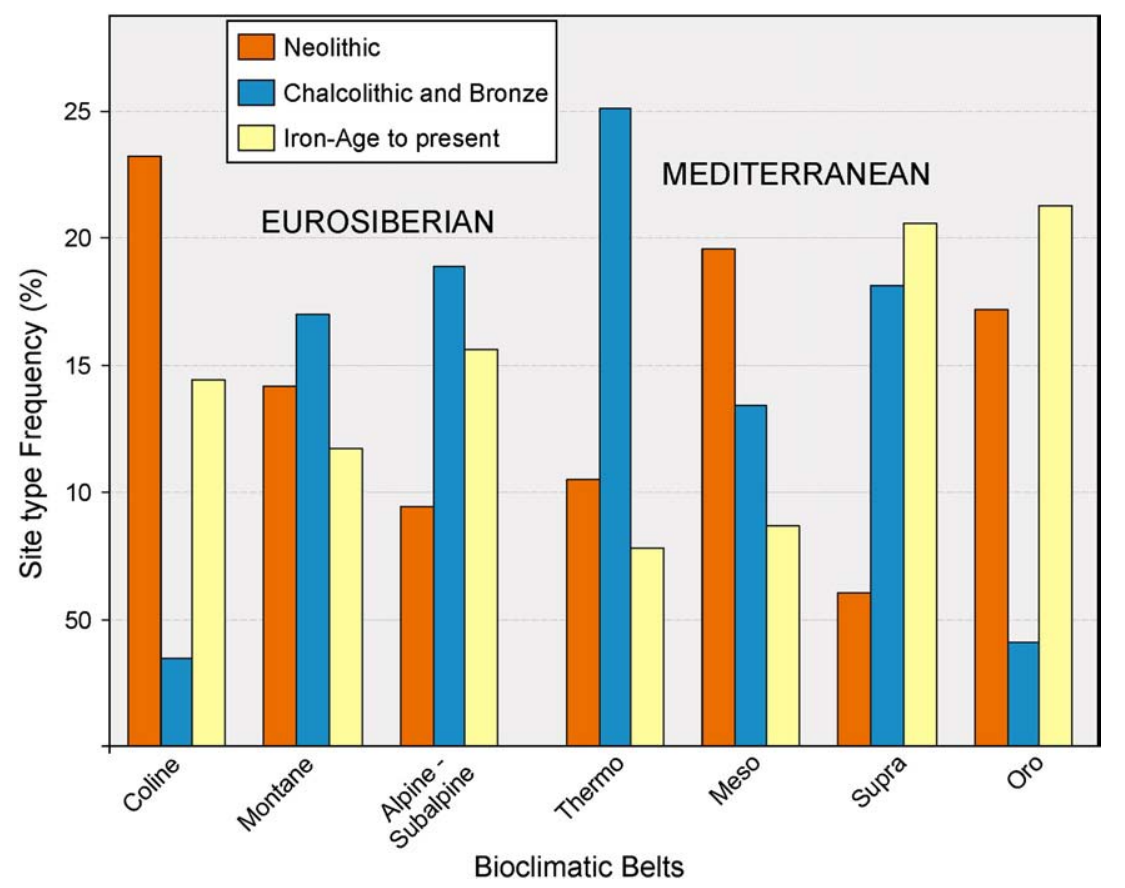

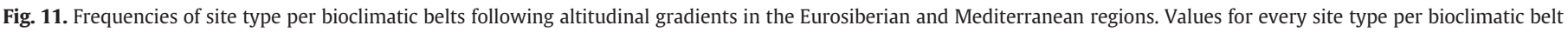
have been weighted by the total number of sites at a particular altitude.

Múgica et al., 2005), Espinosa de Cerrato (Franco-Múgica et al., 2001) (Fig. 7), Villaviciosa (García-Antón et al., 2006), and Leitariegos (GarcíaRovés et al., 2001) show these first impacts only during the last two millennia. Others, like Cañada de la Cruz (Carrión et al., 2001b), Lucenza (Santos et al., 2000), Quintanar de la Sierra (Ruíz-Zapata et al., 2002), and Villuercas (Gil-Romera et al., 2008), register human influences even later. In fact, it is remarkable that some pollen sequences lack anthropogenic pollen indicators (Pantaleón-Cano et al., 2003), and that others correspond primarily to climate changes, in spite of the noted influence of humans (e.g. Taravilla Lake by Moreno et al., 2009).

Aiming to find out whether altitude would play an important role in the distribution of sites, a frequency analysis was carried out (Fig. 11). In order to reduce the bias produced by the dissimilar abundance of sites at different altitudes, the frequency of sites in every period at any specific altitude was weighted by the abundance of total sites in that particular altitude belt. Thus the frequency is not conditioned by the number of sites found for a period but only for the altitude. According to the frequency distribution, the Iberian Peninsula shows plentiful sites with Neolithic impact of man on the vegetation landscapes, probably because of the early development of agriculture. However, the antiquity of their pastoral practices would have also demanded the occupation of rich, fresh high altitude grasslands. Within the Mediterranean Region, the sites with evidence of Chalcolithic-Bronze impacts occur largely below the oromediterranean belt, in regions that, at the time, were probably cooler and wetter than nowadays. These would represent suitable ecological conditions since they were probably providing the resources needed for the intensification of mining and agricultural activities while avoiding unnecessary risk and hazards derived from mountain occupation and facilitating the access to resources given the low altitudes. Since the Roman period onwards the land was widely occupied but, while occupying lowlands sites, the higher mountain belts were also populated.

The history of the vegetation of a number of sites seems clearly influenced by changes in local economy, but there remain technical difficulties in establishing a causal relationship between cultural and environmental changes given the imprecise chronologies available and the fragmentary character of most of the palaeoecological information. One exception is the study carried out in Sierra de Baza and Sierra de Gádor regarding the Argaric culture collapse that took place sharply about c. 3600 cal. yr BP (Carrión et al., 2003, 2007) (Fig. 12). From the fourth to the first half of the third millennia BC in southeastern Spain, the economy was a subsistence one based on mixed pastoral-agricultural strategies. Subsequently, mining is associated with a population increase during the third millennium and throughout the greater part of the second millennium BC. It is the beginning of the first metallurgic communities of the south-eastern Peninsula: the cultures of the Chalcolithic Los Millares and the Argaric Bronze. From the end of the second millennium to the Late RomanHigh Medieval period, there is a depopulation that coincides with the disappearance of the Argaric world and copper-bronze-arsenic metallurgy. The palynological sequences of Baza (Carrión et al., 2007), Gádor (Carrión et al., 2003), Caldereros (Fuentes et al., 2005), in conjunction with other fragmentary palaeobotanical information (Carrión et al., 2007) suggest ecological degradation, landscape opening, fires, pastoralism, and perhaps tree cutting for mining, as the proximate causes of abandonment (Fig. 12). In the southwest Iberian Peninsula, evidence of ecological degradation has been detected from the Chalcolithic. In the beginning of the third millennium BC, intensive copper mining and smelting developed in the Iberian Pyrite Belt of southwestern Spain (Nocete et al., 2005). It was of great magnitude and provoked systematic deforestation and increased erosion and the beginnings of heavy metal pollution in the estuaries of Tinto and Odiel rivers (Gulf of Cádiz). Based on a temporal correlation between the developments and dismantling of territorial networks, Nocete et al. (2005) have inferred a direct link to the development and collapse of the intersocial body of Core/Periphery relationships during this cultural period.

In northern and northwestern Iberia, Muñoz-Sobrino et al. (2005) and López-Merino (2009) found evidence of minor Neolithic-induced transformations, but the Chalcolithic, Bronze, Iron, and Roman phases are most often characterized by profound impacts on the forests, probably linked to the increase of surfaces for agriculture and livestock grazing. Forest clearance, probably linked to mining is also noticed in the Cantabrian region. More recently, a major reforestation 


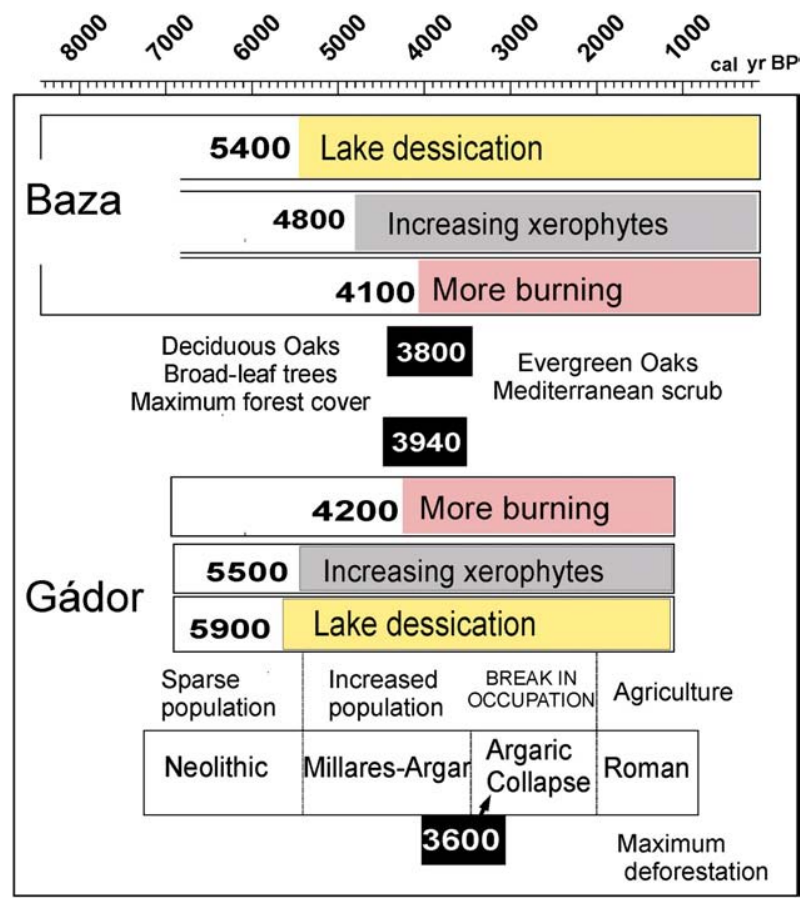

Fig. 12. Vegetational developments in the Sierra de Baza (Carrión et al., 2007) and Sierra de Gádor (Carrión et al., 2003) of southern Spain, and correlation with patterns of human settlement. In both records, increased fire frequency (c. 4200-4100 cal. yr BP) and a change from mixed forests to sclerophyllous forest-scrub (c. 3940-3800 cal. yr BP) precede the collapse of the Argaric Bronze culture at c. 3600 cal. yr BP. A climate trend towards greater aridity is observed ever since c. 5500 cal. yr BP. Ages in black boxes represent the dates of main changes in both sequences.

occurred during the Christian Reconquest and the associated repopulation of the north. Other pulses of population growth include the 12th and 13th centuries (Valdeón et al., 1994) and the Late Middle Ages until the 16th century, in which the reactivation of economy was based on sheep/goat production. Deforestation increased during the 16th century due to the demand of wood for large ship construction during the Spanish colonization of America (Muñoz-Sobrino et al., 2005, and Valbuena et al., in this volume). The last five thousand years have certainly been of great impact, by human economic activity, on the vegetation landscapes of northern Iberia.

The intensity and timing of human impact on vegetation have varied from one part of the Iberian Peninsula to another. In one sense, human activities are a further "unexpected" pathway influencing vegetation dynamics. Changes in demography and economic activities represent historical accidents which may provoke peculiar trajectories in vegetation history, such as seen in the Balearic Islands of Mallorca and Minorca (Fig. 8). Yet, the interpretation of pollen-stratigraphical changes as a result of local human disturbance may be speculative if due account is not taken of the spatial scale of the impact, and of the other physical and biotic influences. How climate, ecological factors, and man activities may interact to produce similarities and divergences in Holocene vegetation sequences is illustrated in the Segura Mountains of southern Spain. Comparison between the main vegetation shifts in the sites of Cañada de la Cruz, Siles, Sabinar, and Villaverde depicts climatically-induced altitudinal displacements of vegetation belts (Carrión, 2002; Carrión et al., 2001b, 2004). However, altitudinal correlation of these taxa is complicated by species interactions, mainly competitive and successional processes among Pinus nigra, P. pinaster, deciduous and evergreen Quercus (Carrión, 2002). A detailed revision of the patterns and processes of vegetation change in Siles (Fig. 13) may provide us with a corollary: climate has, doubtless, exerted long-term control of the species pool, but initiating factors and the inertia of established tree populations, as well as migrational processes interconnected with competition adjustments, were responsible for important time lags in the response of vegetation to climate. Yet, fire disturbance would have been a major factor shaping interspecific relationships and vegetation change from about $4500 \mathrm{cal}$. yr BP onwards. Interestingly, the most obvious anthropogenic phase between 3000 and $1500 \mathrm{cal}$. yr BP corresponds with maximum fire activity and great sensitivity in the vegetation, as could be deduced from the rate-of-change curves (Carrión, 2002).

Among all disturbances shaping the Iberian vegetation through time, the influence of fire is probably the best understood. Fire is now considered an inherent element in the Mediterranean environment, rejuvenating the system and generating new open spaces to be colonized (Carrión-Marco, 2005; Ojeda et al., 2005; Pausas and Keeley, 2009). As stated in the Introduction, understanding the long-term role of fire would allow us to recognize the vegetation response to different forcings. The analyses of past fire regimes, although slowly gaining more importance across Europe and North-America (Carcaillet et al., 2001, 2007; Gavin et al., 2006; Tinner et al., 2006; Anderson et al., 2008; Higuera et al., 2008), are still very much needed in the southern European Peninsulas (Vannière et al., 2008), where both the climate and the pattern of human occupation create a unique fire-prone environment. Fire history reconstruction would help in assessing the post-fire response of pines and oaks, as resprouters or seeders, as this might have been a determinant factor of the ecosystem's resilience and for the competitive relation of broadleaved and coniferous forests. Fire is intimately connected to fuel availability, moisture patterns and therefore to climate changes, but it is also directly linked to human activities. This is particularly well studied in the above-mentioned sequences of the south-eastern region of Iberia (e.g. Carrión et al., 2001a,b, 2003, 2007), where the fire pattern is often independent from the climate trends and it is more subject to the abandonment and reoccupation of different areas.

As we gain more taxonomic detail and stratigraphic resolution in pollen sequences of the Iberian Peninsula, the prevailing climatic paradigm seems increasingly fragile. Vegetation stages recur in time because vegetation is subject to the consequences of physical laws and processes. But particularities must be explained and, in the cases exposed here, it seems that they may appear determined as much as by the biotic history as by abiotic site properties.

\section{Conclusions}

Long-term vegetation dynamics in the Iberian Peninsula are subject to control factors equivalent to those prevailing in Northern Europe. Its landscape diversity, ecological history, fire activity and ancient human occupation, however, have often defined unexpected vegetation responses, especially in the Mediterranean-influenced climate region. Recapitulating our initial hypothesis about Iberian forest reactivity to climate change and human agency we highlight the following aspects:

- In the Eurosiberian, and often also in the Mediterranean region of the Iberian Peninsula, the Lateglacial and Early Holocene are characterized by the development of Quercus-dominated assemblages and other angiosperm trees at the expense of pine woodlands and steppes. The earliest Quercus invasions occur in coastal, oceanic and thermic regions. Mesophytic maxima take place most often during the first Holocene millennia. Continental and high-altitude locations reflect pine prevalence during this period. In those sites with sufficient stratigraphical resolution, the Younger Dryas cold spell is recorded in the form of expansion of xerophytes.

- In the Mediterranean Region, a millennial-scale resilience of the established forests is often observed. Occasionally, this resilience was followed by a threshold response to increased burning in the form of competitively-mediated Quercus invasion during the Mid Holocene. In other cases, the Pinus woodlands remained as dominant 


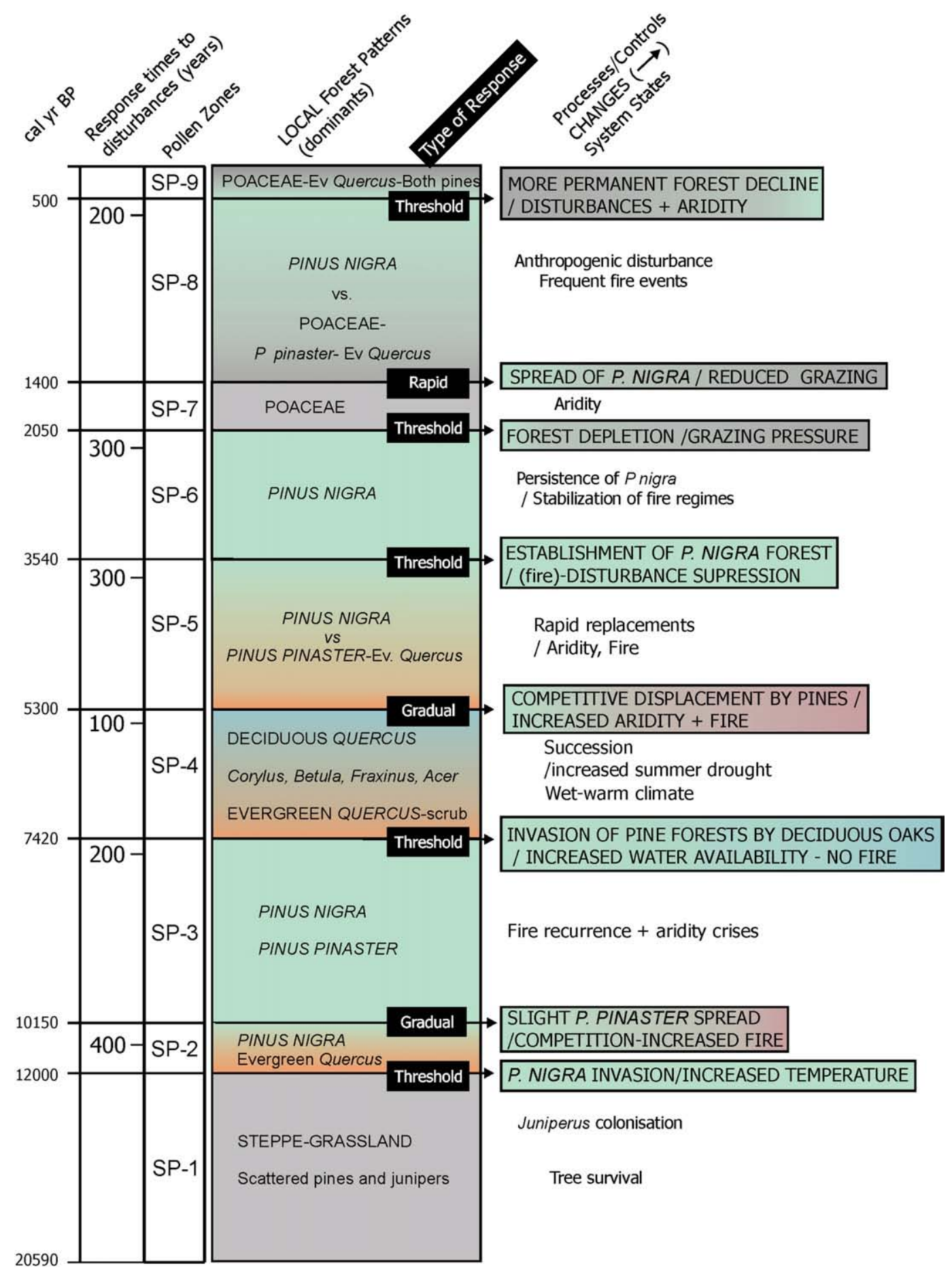

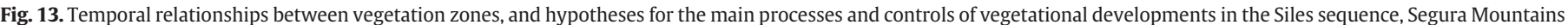

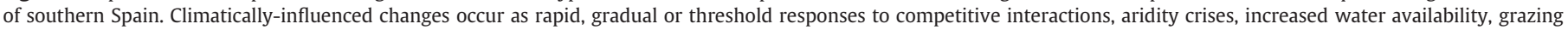

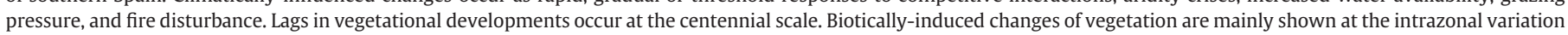
level. Modified from Carrión (2002).

landscapes until the Late Holocene or present day. Vegetational dynamics in the Balearic Islands are diverse and strongly dependent on the floristic composition and human activities.

- Human occupation has played a determinant role shaping the Iberian landscapes as we know them since the Mid-Holocene; grazing, agriculture, mining, coppicing, slash and burn, etc., are all activities exerting deep transformations. As for the climate forcing, anthropogenically induced changes have had, sometimes, unpredictable consequences and complicate the climatic reconstructions.
- As we gain temporal resolution in pollen records, we can see the concentration of the major changes into relatively short episodes; the rate of change is definitively uneven, which points to the need of a conceptualization based in an historical-contingent rather than a deterministic approach.

- In the overall picture, some areas have always been more very sensitive to climate fluctuations and human activities, although the spatial pattern is puzzling. Independent of the area, climate has exerted long-term control of the species pool, but initiating factors 
and the inertia of established tree populations, as well as migrational processes interconnected with competition adjustments, were responsible for important time delays in the response of vegetation. This is so to such an extent that vegetation trajectories are sometimes intricate enough as to predict that historical contingency overwhelms the common trend. The need for more long-term vegetation studies is still very much needed in order to understand the time lags between the three-fold forcing system: climatevegetation-humans.

\section{Acknowledgements}

This research has been funded by the national projects CGL-20096988, CGL-2006-2956-BOS and HAR2008-06477-C03-03/HIST, LIMNOCAL (CGL2006-13327-C04-01), GRACCIE (CSD2007-00067) and Hum2004-04939 MCYT (Ministerio de Educación y Ciencia, Madrid), PEPLAN (Dirección General del Medio Natural Región de Murcia), and Paleodiversitas Network (Fundación Séneca, Murcia).

\section{Appendix A. Supplementary data}

Supplementary data associated with this article can be found, in the online version, at doi:10.1016/j.revpalbo.2009.12.007.

\section{References}

Allen, J.R., Huntley, B., Watts, W., 1996. The vegetation and climate of northwest Iberia over the last 14000 yr. Journal of Quaternary Science 11 (2), 125-147.

Allué, E., 2002. Dinámica de la vegetación y explotación del combustible leñoso durante el Pleistoceno Superior y el Holoceno del noreste de la Península Ibérica a partir del análisis antracológico. Ph.D. thesis, Universitat Rovira i Virgili, Tarragona.

Allué, E., Euba, I., Alarcos, A., González Jiménez, R., Martínez Rodríguez, P., 2006. Noves aportacions al coneixement del medi vegetal i l'explotació del combustible durant el Bronze final a partir de l'anàlisi antracològica de Sta. Digna III (Llerona, Les Franqueses del Vallès). Cypsela 16, 177-181.

Anderson, R.S., Allen, C.D., Toney, J.L., Jass, R.B., Bair, A.N., 2008. Holocene vegetation and fire regimes in subalpine and mixed conifer forests, southern Rocky Mountains, USA. International Journal of Wildland Fire 17, 96-114.

Arroyo, J., Carrión, J.S., Hampe, A., Jordano, P., 2008. La distribución de las especies en diferentes escalas espacio-temporales. In: Valladares, F. (Ed.), Ecología del bosque mediterráneo en un mundo cambiante. Ministerio de Medio Ambiente, Madrid, pp. 29-70.

Atienza, M., 1995. Estudio palinológico de los cambios en el límite superior del bosque durante el Holoceno en la Sierra de Béjar. Sistema Central Español. In: Aleixandre Campos, T., Pérez González, A. (Eds.), Reconstrucción de paleoambientes y cambios climáticos durante el Cuaternario. Monografías 3. Centro de Ciencias Medioambientales, C.S.I.C, Madrid, pp. 329-338.

Aura Tortosa, J.E., Carrión-Marco, Y., García Puchol, O., Jardón Giner, P., Jordá Pardo, J.F., Molina Balaguer, L., Morales Pérez, J.V., Pascual Benito, J.L., Pérez Jordá, G., Pérez Ripoll, M., Rodrigo García, M.J., Verdasco Cebrián, C.C., 2006. EpipaleolíticoMesolítico en las comarcas centrales valencianas. In: Alday Ruiz, A. (Ed.), El Mesolítico de muescas y denticulados en la cuenca del Ebro y el litoral mediterráneo peninsular. Diputación Foral de Álava. Departamento de Cultura, Álava, pp. 65-120.

Badal, E., 1998. El interés económico del pino piñonero para los habitantes de la Cueva de Nerja. In: Sanchidrían Torti, J.L., Simón Vallejo, M.D. (Eds.), Las culturas del Pleistoceno Superior en Andalucía. Patronato de la Cueva de Nerja, Málaga, pp. 287-299.

Badal, E., 2004. Análisis antracológico de los restos del fuego doméstico del abrigo de los Baños (Ariño, Teruel). In: Utrilla, P., Rodanés, J.M. (Eds.), Un asentamiento epipaleolítico en el valle del río Martín. El abrigo de Los Baños (Ariño, Teruel). : Monografías Arqueológicas, vol. 39. Universidad de Zaragoza, pp. 63-73.

Badal, E., 2006. Carbones y cenizas, ¿qué nos cuentan del pasado? In: Carrión, J.S., Fernández, S., Fuentes, N. (Eds.), Paleoambientes y cambio climático. Fundación Séneca. Agencia de Ciencia y Tecnología de la Región de Murcia, pp. 103-116.

Badal, E., Bonet, H., Collado, E., Fabado, J., Fuentes, M., Izquierdo, I., Mata, C., Moreno, A., Ntinou, M., Quixal, D., Ripollès, P.P., Soria, L., 2008. Lo real y lo imaginario. El proyecto Hum2004-04939 sobre la flora en el mundo Ibérico. In: Rovira, S., GarcíaHeras, M., Gener, M., Montero, I. (Eds.), Actas VII Congreso Ibérico de Arqueometría, Madrid, pp. 144-157.

Badal, E., Bernabeu, J., Vernet, J.L., 1994. Vegetation changes and human action from the Neolithic to the Bronze Age (7000-4000 B.P.) in Alicante, Spain, based on charcoal analysis. Vegetation History and Archaeobotany 3, 155-166.

Bennett, K.D., Willis, K.J., 1995. The role of ecological factors in controlling vegetation dynamics on long temporal scales. Giornale Botanico Italiano 129, 243-254.

Bhagwat, S.A., Willis, K.J., 2008. Species persistence in northerly glacial refugia of Europe: a matter of chance or biogeographical traits? Journal of Biogeography 35, 464-482.

Birks, H.J.B., 1986. Late Quaternary biotic changes in terrestrial and lacustrine environments, with particular reference to north-west Europe. In: Berglund, B.E.
(Ed.), Handbook of Holocene palaeoecology and palaeohydrology. Wiley, Chichester, pp. 3-65.

Bradley, R.S., 2008. Holocene perspectives on future climate change. In: Battarbee, R.W. Binney, H.A. (Eds.), Natural Climate Variability and Global Warming: a Holocene Perspective. Wiley-Blackwell, Chichester, pp. 254-268.

Brewer, S., Cheddadi, R., de Beaulieu, J.L., Reille, M., 2002. The spread of deciduous Quercus throughout Europe since the last glacial period. Forest Ecology and Management 156, 27-48.

Bueno, P., Barroso, R., Balbín, R., Campo, M., Exteberría, F., González, A., Herrasti, L., Treserras, J.J., López-García, P., López-Sáez, J.A., Matamala, J.C., Sánchez, B., 2002. Áreas habitacionales y funerarias en el Neolítico de la cuenca interior del Tajo: la provincia de Toledo. Trabajos de Prehistoria 59 (2), 65-79.

Burjachs, F., 1988. Análisis polínico de los niveles cerámicos de la "Cova 120" (Alta Garrotxa, Catalunya). Acta Salmanticensia 65, 285-290.

Burjachs, F., Renault-Miskovsky, J., 1992. Paléoenvironnement et paléoclimatologie de la Catalogne durant pres de 30000 ans (du Würmien ancien au début de l'Holocène) d’apres la palynologie du site de l'Arbreda (Gerone, Catalogne). Quaternaire 3 (2), 75-85.

Burjachs, F., Riera, S., 1995. Canvis vegetals i climàtics durant el Neolític a la façana mediterrània ibèrica. Rubricatum 1, 21-27.

Burjachs, F., Expósito, I., 2007. 4.2.2. El paisatge vegetal. In: Carlús, X., López-Cachero, F. J., Oliva, M., Palomo, A., Rodríguez Lázaro, A., Terrats, N., Lara, C., Villena, N. (Eds.), Cabanes, sitges i tombes: El paratge de Can Roqueta (Sabadell, Vallès Occidental) del 1300 al 500 AC. Quaderns d'Arqueologia 4. Museu d'Història de Sabadell Ajuntament de Sabadell, Sabadell, pp. 72-73.

Burjachs, F., Pérez-Obiol, R., Roure, J.M., Julià, R., 1994. Dinámica de la vegetación durante el Holoceno en la isla de Mallorca. In: Mateu, I., Dupré, M., Güemes, J. Burgaz, M.E. (Eds.), Trabajos de Palinología básica y aplicada. Universitat de València, València, pp. 199-210.

Burjachs, F., Comín, F., Rodó, X., 1996. Gallocanta: ejemplo de secuencia palinológica en una laguna efímera. In: Ruiz-Zapata, B. (Ed.), Estudios Palinológicos. Servicios de Publicaciones de la Universidad de Alcalá, Alcalá de Henares, pp. 25-29.

Burjachs, F., Giralt, S., Roca, J.R., Seret, G., Julià, R., 1997. Palinología holocénica y desertización en el Mediterráneo occidental. In: Ibáñez, J.J., Valero, B.L., Machado, C. (Eds.), El paisaje mediterráneo a través del espacio y del tiempo. Implicaciones en la desertificación. Geoforma Editores, Logroño, pp. 379-394.

Buxó, R., 1997. Arqueología de las plantas. La explotación económica de las semillas y los frutos en el marco mediterráneo de la Península Ibérica, Crítica, Barcelona. 367 pp

Cacho, C., Fumanal, M.P., López-García, P., López-Sáez, J.A., Pérez Ripoll, M., Martínez Valle, R., Uzquiano, P., Arnanz, A., Sánchez Marco, A., Sevilla, P., Morales, A., Roselló, E., Garralda, M.D., García Carrillo, M., 1995. El Tossal de la Roca (Vall d' Alcalá, Alicante). Reconstrucción paleoambiental y cultural de la transición del Tardiglaciar al Holoceno inicial. Recerques del Museu d'Alcoi 4, 11-101.

Cámalich, M.D., Martín, D., 1999. El territorio almeriense desde los inicios de la producción hasta fines de la antigüedad. Un modelo: la Depresión de Vera y Cuenca del Río Almanzora. Arqueología, Monografías, Junta de Andalucía, Sevilla.

Carcaillet, C., Bergeron, Y., Richard, P.J.H., Frechette, B., Gauthier, S., Prairie, Y.T., 2001 Change of fire frequency in the eastern Canadian boreal forests during the Holocene: does vegetation composition or climate trigger the fire regime? Journal of Ecology 89, 930-946.

Carcaillet, C., Bergman, I., Delorme, S., Hornberg, G., Zackrisson, O., 2007. Long-term fire frequency not linked to prehistoric occupations in northern Swedish boreal forest. Ecology 88, 465-477.

Carrión-Marco, Y., 2003. Afinidades y diferencias en las secuencias antracológicas en las vertientes mediterránea y atlántica de la Península Ibérica. Ph.D. thesis, Universitat de València, Valencia.

Carrión-Marco, Y., 2004. Análisis antracológico del yacimiento de Fuente Álamo (Cuevas del Almanzora, Almería): usos de la madera y paleovegetación. In: Hernández, L., Hernández, M. (Eds.), Congreso sobre la Edad del Bronce en las tierras valencianas y zonas limítrofes. Universidad de Alicante, pp. 477-486.

Carrión-Marco, Y., 2005. La vegetación mediterránea y atlántica de la península Ibérica. Nuevas secuencias antracológicas. Trabajos Varios de S.I.P. (Servicio de Investigación Prehistórica) 104. Diputación Provincial de Valencia, Valencia. 314 pp.

Carrión, J.S., 1992. Late Quaternary pollen sequence from Carihuela Cave, southeastern Spain. Review of Palaeobotany and Palynology 71, 37-77.

Carrión, J.S., 2001a. Dialectic with climatic interpretations of Late-Quaternary vegetation history in Mediterranean Spain. Journal of Mediterranean Ecology 2, 145-156.

Carrión, J.S., 2001b. Pastoreo y vulnerabilidad de la vegetación en la alta montaña mediterránea durante el Holoceno. Cuadernos de Geografía 69 (70), 7-22.

Carrión, J.S., 2002. Patterns and processes of Late Quaternary environmental change in a montane region of southwestern Europe. Quaternary Science Reviews 21, 2047-2066.

Carrión, J.S., Dupré, M., 1996. Late Quaternary vegetational history at Navarrés, eastern Spain. A two-core approach. New Phytologist 134, 177-191.

Carrión, J.S., van Geel, B., 1999. Fine-resolution Upper Weichselian and Holocene palynological record from Navarrés (Valencia, Spain) and a discussion about factors of Mediterranean forest succession. Review of Palaeobotany and Palynology 106, 209-236.

Carrión, J.S., Navarro, C., 2002. Cryptogam spores and other non-pollen microfossils as sources of palaeoecological information: case-studes from Spain. Annales Botanici Fennici 39, 1-14.

Carrión, J.S., Munuera, M., Navarro, C., Sáez, F., 2000. Paleoclimas e historia de la vegetación cuaternaria en España a través del análisis polínico. Viejas falacias y nuevos paradigmas. Complutum 11, 115-142.

Carrión, J.S., Andrade, A., Bennet, K.D., Navarro, C., Munuera, M., 2001a. Crossing forest thresholds: inertia and collapse in a Holocene sequence from south-central Spain. The Holocene 11 (6), 635-653. 
Carrión, J.S., Munuera, M., Dupré, M., Andrade, A., 2001b. Abrupt vegetation changes in the Segura Mountains of southern Spain throughout the Holocene. Journal of Ecology 89, 783-797.

Carrión, J.S., Sánchez-Gómez, P., Mota, J.F., Yll, E.I., Chaín, C., 2003. Fire and grazing are contingent on the Holocene vegetation dynamics of Sierra de Gádor, southern Spain. The Holocene 13, 839-849.

Carrión, J.S., Willis, K.J., Sánchez Gómez, P., 2004. Holocene forest history of the eastern plateaux in the Segura Mountains (Murcia, southeastern Spain). Review of Palaeobotany and Palynology 132, 219-236.

Carrión, J.S., Fuentes, N., González-Sampériz, P., Quirante, L.S., Finlayson, J.C., Fernandez, S., Andrade, A., 2007. Holocene environmental change in a montane region of southern Europe with a long history of human settlement. Quaternary Science Reviews 26, 1455-1475.

Carrión, J.S., Finlayson, C., Férnández, S., Finlayson, G., Allué, E., López-Sáez, J.A., LópezGarcía, P., Gil-Romera, G., Bailey, G., González-Sampériz, P., 2008. A coasta reservoir of biodiversity for Upper Pleistocene human populations: palaeoecological investigations in Gorham's Cave (Gibraltar) in the context of the Iberian Peninsula. Quaternary Science Reviews 27, 2118-2135.

Carrión, J.S., Fernández, S., Jiménez-Moreno, G., Fauquette, S., Gil-Romera, G., GonzálezSampériz, P., Finlayson, C., 2009. The historical origins of aridity and vegetation degradation in southeastern Spain. Journal of Arid Environments. doi:10.1016/j. jaridenv.2008.11.014

Castro, P.V., Chapman, R.W., Suriñach, S., Lull, V., Micó, R., Rihuete, C., Risch, R., Sanahuja, M.E., 1999. Proyecto Gatas 2. La dinámica arqueoecológica de la ocupación prehistórica, Arqueología, Monografías, Junta de Andalucía, Sevilla. 426 pp.

Conedera, M., Krebs, P., Tinner, W., Pradella, M., Torriani, D., 2004. The cultivation of Castanea sativa (Mill.) in Europe, from its origin to its diffusion on a continental scale. Vegetation History and Archaeobotany 13, 161-179.

Cortés Sánchez, M., Morales Muñiz, A., Simón Vallejo, M.D., Bergadà Zapata, M.M. Delgado Huertas, A., López-García, P., López-Sáez, J.A., Lozano Francisco, M.C. Riquelme Cantal, J.A., Roselló Izquierdo, E., Sánchez Marco, A., Vera Peláez, J.L. 2008. Palaeoenvironmental and cultural dynamics of the coast of Málaga (Andalusia, Spain) during the Upper Pleistocene and Early Holocene. Quaternary Science Reviews 27, 2176-2193.

Davis, B.A.S., Stevenson, A.C., 2007. The 8.2 ka event and early-mid Holocene forests fires and flooding in the Central Ebro Desert, NE Spain. Quaternary Science Reviews $26,1695-1712$

Díez, A., Bateman, M.D., López-Sáez, J.A., Vegas, J., 2002. Procesos eólicos tardiglaciares en la Submeseta septentrional: cronología del manto arenoso de la Tierra de Pinares. In: Pérez, A., Vegas, J., Machado, M.J. (Eds.), Aportaciones a la geomorfología de España en el inicio del Tercer Milenio. IGME-S.E.G., Madrid, pp. 167-175.

Dorado-Valiño, M., Valdeolmillos Rodriguez, A., Ruiz-Zapata, B., Gil-García, M.J., de Bustamante Gutiérrez, I., 2002. Climatic changes since the Late-glacial/Holocene transition in La Mancha Plain (South-central Iberian Peninsula, Spain) and their incidence on Las Tablas de Daimiel marshlands. Quaternary International 93 (94), $73-84$.

Dupré, M., 1988. Palinología y paleoambiente. Nuevos datos españoles. Referencias. Servicio de Investigación Prehistórica. Serie de Trabajos Varios, 84, Valencia.

Dupré, M., Fumanal, M.P., Martínez Gallego, J., Pérez Obiol, R., Roure, J.M., Usera, J., 1996 The Laguna de San Benito (Valencia, Spain): palaeoenvironmental reconstruction of an endorheic system. Quaternaire 7 (4), 177-186.

Fernández, S., Fuentes, N., Carrión, J.S., González-Sampériz, P., Montoya, E., Gil, G., Vega Toscano, G., Riquelme, J.A., 2007. The Holocene and Upper Pleistocene pollen sequence of Carihuela Cave, southern Spain. Geobios 40, 75-90.

Figueiral, I., 1993. Charcoal analysis and the vegetation evolution of northwest Portugal. Oxford Journal Archaeology 12 (2), 209-222.

Figueiral, I., 1995. Charcoal analysis and the history of Pinus pinaster (cluster pine) in Portugal. Review of Palaeobotany and Palynology 89, 441-454.

Figueiral, I., Terral, J.F., 2002. Late quaternary refugia of Mediterranean taxa in the Portuguese Estremadura: charcoal based palaeovegetation and climatic reconstruction. Quaternary Science Reviews 21, 549-558.

Finlayson, C., Carrión, J.S., 2007. Rapid ecological turnover and its impact on Neandertha and other human populations. Trends in Ecology and Evolution 22 (4), 213-222.

Fletcher, W.J., Boski, T., Moura, D., 2007. Palynological evidence for environmental and climatic change in the lower Guadiana valley, Portugal, during the last 13000 years. The Holocene 17 (4), 481-494.

Fombella Blanco, M.A., García-Rovés, E., Puente, E., 2003. Comparative palynological analysis between the San Isidro and Leitariegos Holocene sequences, NW Spain. Acta Paleontologica Sinica 42 (1), 111-117.

Franco-Múgica, F., García-Antón, M., Sainz Ollero, H., 1997. Impacto antrópico y dinámica de la vegetación durante los últimos 2000 años BP en la vertiente septentrional de la Sierra de Gredos: Navarredonda (Ávila, España). Revue de Paléobiologie 16 (1), 29-45.

Franco-Múgica, F., García-Antón, M., Maldonado Ruiz, J., Morla Juaristi, C., Sainz Ollero, H., 2001. The Holocene history of Pinus forest in the Spanish Northern Meseta. The Holocene 11 (3), 343-358.

Franco-Múgica, F., García-Antón, M., Maldonado Ruiz, J., Morla Juaristi, C., Sainz-Ollero H., 2005. Ancient pine forest on inland dunes in the Spanish Northern meseta. Quaternary Research 63,1-14

Fuentes, N., García Martínez, M., González-Sampériz, P., Fernández, S., Carrión, J.S., Ros, M., López Campuzano, M., Medina, J., 2005. Degradación ecológica y cambio cultural durante los últimos cuatro mil años en el sureste ibérico semiárido. Anales de Biología 27, 69-84

Fuentes, N., Carrión, J.S., Fernández, S., Nocete, F., Lizcano Prestel, R., Pérez, C., 2007 Análisis polínico de los yacimientos arqueológicos Cerro del Alcázar de Baeza y Eras del Alcázar de Úbeda (Jaén). Anales de Biología 29, 85-93.
García-Antón, M., Gil Romera, G., Pagés, J.L., Alonso Millán, A., 2006. The Holocene pollen record in the Villaviciosa Estuary (Asturias, North of Spain) in relation to changes in sea level. Palaeogeography, Palaeoclimatology, Palaeoecology 237, 280-292.

García, M.S., Grau, E., 2005. Aprovechamiento de los recursos leñosos en la fase protohistórica de Punta de los Gavilanes (Mazarrón, Murcia). Anales de Prehistoria y Arqueología 21, 51-68.

García-Amorena, I., Gómez Manzaneque, F., Rubiales, J.M., Granja, H.M., Soares de Carvalho, G., Morla, C., 2007. The Late Quaternary coastal forests of western Iberia; a study of their macroremains. Palaeogeography, Palaeoclimatology, Palaeoecology 254, 448-461.

García-Amorena, I., Morla, C., Rubiales, J.M., Gómez Manzaneque, F., 2008. Taxonomic composition of the Holocene forests of the northern coast of Spain, as determined from their macroremains. The Holocene 18, 819-829.

García-Rovés, E., Puente García, E., Fombella Blanco, M.A., Ruiz-Zapata, M.B., Marcos Varela, L., 2001. Primeros resultados palinológicos de la turbera del Puerto de Leitariegos, Provincia de León. In: Moreno Grau, S., Elvira Rendueles, B., Moreno Angosto, J.M. (Eds.), XIII Simposio de la Asociación de Palinólogos en Lengua Española (A.P.L.E.). Universidad Politécnica de Cartagena, Cartagena, pp. 283-290.

García-Rovés, E., 2007. Dinámica de la Paleovegetación y cambios climáticos durante el Tardiglaciar y Holoceno en secuencias sedimentarías de la provincia de León. Ph.D thesis, Universidad de León.

Gasse, F., 2000. Hydrological changes in the African tropics since the Last Glacial Maximum. Quaternary Science Reviews 19, 189-211.

Gavin, D.G., Hu, F.S., Lertzman, K., Corbett, P., 2006. Weak climatic control of stand-scale fire history during the Late Holocene. Ecology 87, 1722-1732.

Gil-García, M.J., Dorado-Valiño, M., Valdeolmillos Rodríguez, A., Ruiz-Zapata, M.B., 2002. Late-glacial and Holocene palaeoclimatic record from Sierra de Cebollera (northern Iberian Range, Spain). Quaternary International 93 (94), 13-18.

Gil-García, M.J., Ruiz-Zapata, M.B., 2004. Desarrollo de la vegetación durante el Tardiglaciar y el Holoceno en la Sierra de Cameros (La Rioja. España). Implicaciones climáticas y antrópicas. Zubía 22, 237-250.

Gil-García, M.J., Ruiz-Zapata, M.B., Santisteban, J.I., Mediavilla, R., López-Pamo, E., Dabrio, C. J., 2007. Late Holocene environments in Las Tablas de Daimiel (south central Iberian peninsula, Spain). Vegetation History and Archaeobotany 16, 241-250.

Gil-Romera, G., García-Antón, M., Calleja Alarcón, J.A., 2008. The Holocene palaeoecological sequence of Serranía de las Villuercas in south-western Spain. Vegetation History and Archaeobotany 17, 653-666.

Gil-Romera, G., Carrión, J.S., McClure, S., Schmich, S., Finlayson, C., 2009. Holocene vegetation dynamics in Mediterranean Iberia: historical contingency and climatehuman interactions. Journal of Anthropological Research 65, 271-285.

Giralt, S., Burjachs, F., Roca, J.R., Julià, R., 1999. Late Glacial to Early Holocene environmental adjustment in the Mediterranean semi-arid zone of the Salines playa-lake (Alacant, Spain). Journal of Paleolimnology 21, 449-460.

Gómez, A., Lunt, D.H., 2007. Refugia within refugia: patterns of phylogeographic concordance in the Iberian Peninsula. In: Weiss, S., Ferrand, N. (Eds.), Phylogeography in southern European refugia: evolutionary perspectives on the origins and conservation of European biodiversity. Kluwer, Dordrecht, pp. 155-188.

Gómez-Aparicio, L., Canham, L.D., 2008. Neighborhood models of the effects of invasive tree species on ecosystem processes. Ecological Monographs 78, 69-86.

Gómez-Aparicio, L., Gómez, J.M., Zamora, R., Boettinger, J.L., Ezcurra, E., 2005. Canopy vs. soil effects of shrubs facilitating tree seedlings in Mediterranean montane ecosystems. Journal of Vegetation Science 16, 191-198.

Gómez-Orellana, L., Ramil-Rego, P., Muñoz-Sobrino, C., 1998. Una nueva secuencia polínica y cronológica para el depósito pleistoceno de Mougás (NW de la Península Ibérica). Revue de Paléobiologie 17 (1), 35-47.

González-Sampériz, P., 2004. Evolución paleoambiental del sector central de la cuenca del Ebro durante el Pleistoceno Superior y Holoceno. Instituto Pirenaico de Ecología-CSIC, Zaragoza. 210 pp.

González-Sampériz, P., Valero-Garcés, B.L., Carrión, J.S., Peña, J.L., García Ruiz, J.M., Sancho, C., Martí Bono, C. 2005. Glacial and Lateglacial vegetation in northeastern Spain: new data and a review. Quaternary International 140 (141), 4-20.

González-Sampériz, P., Valero-Garcés, B.L., Moreno, A., Jalut, G., García-Ruiz, J.M., MartíBono, C., Delgado-Huertas, A., Navas, A., Otto, T., Dedoubat, J.J., 2006. Climate variability in the Spanish Pyrenees during the last $30,000 \mathrm{yr}$ revealed by the El Portalet sequence. Quaternary Research 66 (1), 38-52.

González-Sampériz, P., Valero-Garcés, B.L., Moreno, A., Morellón, M., Navas, A., Machín, J., Delgado-Huertas, A., 2008. Vegetation changes and hydrological fluctuations in the Central Ebro Basin (NE Spain) since the Late Glacial period: saline lake records. Palaeogeography, Palaeoclimatology, Palaeoecology 259 (2-3), 157-181.

González-Sampériz, P., Utrilla, P., Mazo, C., Valero-Garcés, B.L., Sopena, M.C., Morellón, M., Sebastián, M., Moreno, A., Martínez-Bea, M., 2009. Patterns of human occupation during the Early Holocene in the Central Ebro Basin (NE Spain) in response to the 8.2 ka climatic event. Quaternary Research 71 (2), 121-132.

Grau, E., 1990. El uso de la madera en yacimientos de la Edad del Bronze a época visigoda. Datos etnobotánicos y reconstrucción ecológica según la antracología. Ph. D. thesis, Universidad de Valencia, Valencia.

Heinz, C., 1991. Upper Pleistocene and Holocene vegetation in the South of France and Andorra. Adaptations and firsts ruptures: new charcoal analysis data. Review of Paleobotany and Palynology 69, 299-324.

Higuera, P.E., Brubaker, L.B., Anderson, P.M., Brown, T.A., Kennedy, A.T., Hu, F.S., 2008. Frequent fires in ancient shrub tundra: implications of paleorecords for arctic environmental change. PLoS ONE 3 (3), e0001744.

Hooghiemstra, H., Stalling, H., Agwu, Ch.O.C., Dupont, L.M., 1992. Vegetational and climatic changes at the northern fringe of the Sahara 250, 000-5000 years BP: evidence from 4 marine pollen records located between Portugal and the Canary Islands. Review of Palaeobotany and Palynology 74, 1-53. 
Jalut, G., Esteban, A., Bonnet, L., Gauquelin, T., Fontugne, M., 2000. Holocene climatic changes in the western Mediterranean, from south-east France to south-east Spain. Palaeogeography, Palaeoclimatology, Palaeoecology 160, 255-290.

Janssen, C.R., 1994. Palynological indications for the extent of the impact of man during Roman times in the western part of the Iberian Peninsula. In: Frenzel, B. (Ed.) Evaluation of land surfaces cleared from forests in the Mediterranean Region during the time of the Roman Empire. Paleoclimate research. Gustav Fischer, Stuttgart, pp. 15-22

Jiménez Sánchez, M., Ruiz-Zapata, M.B., Farias Arquer, P., Dorado-Valiño, M., Gil-García, M. J., Valdeolmillos Rodríguez, A., 2003. Palaeoenviromental research in Cantabrian Mountains: Redes Natural Park and Comella Basin. In: Ruíz-Zapata, M.B., DoradoValiño, M., Valdeolmillo Rodríguez, A., Gil-García, M.J., Bardají Azcárate, T., Bustamante Gutiérrez, I., Martínez Mendizábal, I. (Eds.), Quaternary climatic changes and environmental crises in the Mediterranean Region. Universidad de Alcalá de Henares, Ministerio de Ciencia y Tecnología, INQUA, Alcalá de Henares, pp. 229-240.

Jiménez, P., López-de-Heredia, U., Collada, C., Lorenzo, Z., Gil, L., 2004. High variability of chloroplast DNA in three Mediterranean evergreen oaks indicates complex evolutionary history. Heredity 93, 510-515.

Lamb, H.F., Gasse, F., Benkaddour, A., El Hamouti, N., van der Kaars, S., Perkins, W.T. Pearce, N.J., Roberts, C.N., 1995. Relation between century-scale Holocene arid intervals in tropical and temperate zones. Nature 373, 134-137.

Lauritzen, S.E., 1996. Calibration of speleothem stable isotope against historical records: a Holocene temperature curve for north Norway? Climatic change: the karst record. In: Lauritzen, S.E. (Ed.), Karst Waters Institute Special Publication $\mathrm{n}^{0} 2$ 2. Charles Town, West Virginia, pp. 78-80.

Leroy, S.A.G., Arpe, K., 2007. Glacial refugia for summer-green trees in Europe and south-west Asia as proposed by ECHAM3 time-slice atmospheric model simulations. Journal of Biogeography 34 (12), 2115-2128.

López de Heredia, U., Carrión, J.S., Jiménez, P., Collada, C., Gil, L., 2007. Molecular and palaeobotanical evidence for multiple glacial refugia for evergreen oaks in the Iberian Peninsula. Journal of Biogeography 34, 1505-1517.

López-García, P., 1977. Análisis polínico de Verdelpino (Cuenca). In: Moure Romanillo, J.A., Fernández-Miranda, M. (Eds.), El abrigo de Verdelpino (Cuenca). Noticias de los trabajos de 1976. Apéndice II: Trabajos de Prehistoria, vol. 34, pp. 31-83.

López-García, P., Arnanz, A., Uzquiano, P., López-Sáez, J.A., 1997. Los elementos antrópicos en los análisis arqueobotánicos como indicadores de los usos del suelo. In: García Ruiz, J.M., López-García, P. (Eds.), Acción humana y desertificación en ambientes mediterráneos. Instituto Pirenaico de Ecología, Zaragoza, pp. 41-59.

López-García, P., Arnanz, A., Uzquiano, P., Macías, R., Gil, P., 2003. Informes Técnicos: 1 Paleobotánica. In: Estremera, M.S. (Ed.), Primeros agricultores y ganaderos en la Meseta Norte: el Neolítico de la Cueva de la Vaquera (Torreiglesias, Segovia). : Memorias de Arqueología en Castilla y León, vol. 11. Junta de Castilla y León, Zamora, pp. 247-256.

López-Merino, L., 2009. Paleoambiente y antropización en Asturias durante el Holoceno. Ph.D. thesis. Universidad Autónoma de Madrid, Madrid.

López-Merino, L., López-Sáez, J.A., Ruíz-Zapata, M.B., Gil-García, M.J., 2008. Reconstructing the history of beech (Fagus sylvatica L.) in the north-western Iberian Range (Spain): from Late-Glacial refugia to the Holocene anthropic-induced forests. Review of Palaeobotany and Palynology 152, 58-65.

López-Sáez, J.A., 2002. Análisis paleopalinológico del yacimiento Dehesa de Río Fortes (Mironcillo, Ávila). Boletín del Seminario de Estudios de Arte y Arqueología 68, 42-48.

López-Sáez, J.A., López-Merino, L., 2005. Precisiones metodológicas acerca de los indicios paleopalinológicos de agricultura en la Prehistoria de la Península Ibérica. Portugalia 26, 53-64.

López-Sáez, J.A., López-Merino, L., 2007. Coprophilous fungi as a source of information on anthropic activities during the Prehistory in the Amblés Valley (Ávila, Spain): the archaeopalynological record. Revista Española de Micropaleontología 39 (1-2), 103-116.

López-Sáez, J.A., van Geel, B., Farbos-Texier, S., Diot, M.F., 1998. Remarques paléoécologiques à propos de quelques palynomorphes non-polliniques provenant de sédiments quaternaires en France. Revue de Paléobiologie 17 (2), 445-459.

López-Sáez, J.A., van Geel, B., Martín Sánchez, M., 2000. Aplicación de los microfósiles no polínicos en Palinología Arqueológica. In: Oliveira Jorge, V. (Coord. Ed.), Contributos das Ciências e das Technologias para a Arqueologia da Península Ibérica. Actas $3^{\circ}$ Congresso de Arqueologia Peninsular, vol. 9, Vila-Real, Portugal. Adecap, Porto, pp. 11-20.

López-Sáez, J.A., López-García, P., Burjachs, F., 2003. Arqueopalinología: Síntesis crítica. Polen 12, 5-35.

López-Sáez, J.A., López-García, P., López-Merino, L., Cerrillo Cuenca, E., González Cordero, A., Prada, A., 2005. Prehistoric landscapes in North Extremadura between the VIth and the IVth millenia cal. BC. Journal of Iberian Archaeology 7, 23-35.

López-Sáez, J.A., González Cordero, A., Cerrillo Cuenca, E., 2007. Paleoambiente y paleoeconomía durante el Neolítico antiguo y el Calcolítico en Extremadura: análisis arqueopalinológico del yacimiento del Cerro de la Horca (Plasenzuela, Cáceres, España). Zephyrus 60, 145-153.

Magri, D., Vendramin, G., Comps, B., Dupanloup, I., Geburek, Th., Gömöry, D., Latalowa, M., Litt, Th., Paule, L., Roure, J.M., Tantau, I., van de Knaap, W.O., Petit, R.J., Beaulieu, J.L., 2006. A new scenario for the Quaternary history of European beech populations: Palaeobotanical evidence and genetic consequences. New Phytologist 171, 199-221.

Martínez-Atienza, F., 1999. Bibliografía (1945-1998) paleopolínica del Holoceno ibérico. Boletín de la Real Sociedad Española de Historia Natural (Sección Biológicas) 95, 5-30.

Mateus, J.E., 1989. Lagoa Travessa: a Holocene pollen diagram from the south-west coast of Portugal. Revista de Biología 14, 17-94.
Mayewski, P.A., Rohling, E.E., Stager, J.C., Karlén, W., Maasch, K.A., Meeker, L.D. Meyerson, E.A., Gasse, F., van Kreveld, S., Holmgren, K., Lee-Thorp, J., Rosqvist, G., Rack, F., Staubwasser, M., Schneider, R.R., Steig, E.J., 2004. Holocene climate variability. Quaternary Research 62, 243-255.

Medail, F., Diadema, K., 2009. Glacial refugia influence plant diversity patterns in the Mediterranean Basin. Journal of Biogeography 36, 1333-1345.

Montserrat, J., Vilaplana, J.M., 1987. The paleoclimatic records of the Upper Pleistocene and Holocene in the Llauset Valley (Central Southern Pyrenees). Pirineos 129, 107-113.

Montserrat, J., 1992. Evolución glaciar y postglaciar del clima y la vegetación en la vertiene sur del Pirineo: Estudio palinológico. Monografías del Instituto Pirenaico de Ecología 6. Instituto Pirenaico de Ecología, CSIC, Zaragoza.

Moreno, A., López-Merino, L., Leira, M., Marco Barba, J., González-Sampériz, P., ValeroGarcés, B.L., López-Sáez, J.A., Santos, L., Mata, P., Ito, E., 2009. Revealing Holocene environmental history from the multiproxy record of a mountain lake (Lago Enol, N Iberian Peninsula). Journal of Paleolimnology. doi:10.1007/s10933-009-9387-7.

Muñoz-Sobrino, C., Ramil-Rego, P., Rodríguez Guitián, M., 1997. Upland vegetation in the north-west Iberian Peninsula after the last glaciation: forest history and deforestation dynamics. Vegetation History and Archaeobotany 6, 215-233.

Muñoz-Sobrino, C., Ramil-Rego, P., Rodríguez Guitián, M.A., 2001. Vegetation in the mountains of northwest Iberia during the last glacial-interglacial transition. Vegetation History and Archaeobotany 10, 7-21.

Muñoz-Sobrino, C., Ramil-Rego, P., Gómez-Orellana, L., 2004. Vegetation of the Lago de Sanabria area (NW Iberia) since the end of the Pleistocene: a palaeoecological reconstruction on the basis of two new pollen sequences. Vegetation History and Archaeobotany 13, 1-22

Muñoz-Sobrino, C., Ramil-Rego, P., Gómez-Orellana, L., Díaz Varela, R.A., 2005 Palynological data on major Holocene climatic events in NW Iberia. Boreas 34, 381-400.

Muñoz-Sobrino, C., Ramil-Rego, P., Gomez Orellana, L., 2007. Late Würm and Early Holocene in the mountains of northwest Iberia: biostratigraphy, chronology and tree colonization. Vegetation History and Archaeobotany 16, 223-240.

Muñoz-Sobrino, C., Ramil-Rego, P., Gómez-Orellana, L., Ferreiro da Costa, J., Díaz Varela R.A., 2009. Climatic and human effects on the post-glacial dynamics of Fagus sylvatica L. in NW Iberia. Plant Ecology 203, 317-340.

Naughton, F., Sánchez Goñi, M.F., Desprat, S., Turon, J.L., Duprat, J., Malaize, B., Joli, C., Cortijo, E., Drago, T., Freitas, M.C., 2007. Present-day and past (last 25000 years) marine pollen signal off western Iberia. Marine Micropaleontology 62, 91-114.

Nocete, F., Alex, E., Nieto, J.M., Sáez, R., Bayona, M.R., 2005. An archaeological approach to regional environmental pollution in the south-western Iberian Peninsula related to Third millennium BC mining and metallurgy. Journal of Archaeological Science 32, 1566-1576.

Ojeda, F., Brun, F.G., Vergara, J.J., 2005. Fire, rain and the selection of seeder and resprouter life-histories in fire-recruiting, woody plants. New Phytologist 168 155-165.

Pantaleón-Cano, J., 1997. Estudi palinològic de sediments litorals de la provincia d'Almería. Transformacions del paitsatge vegetal dins un territori semiàarid. Ph.D. thesis, Universitat Autonoma de Barcelona.

Pantaleón-Cano, J., Pérez-Obiol, R., Yll, E.I., Roure, J.M., 1996. Significado de Pseudoschizaea en secuencias sedimentarias de la vertiente mediterránea de la Península Ibérica e Islas Baleares. In: Ruíz-Zapata, M.B. (Ed.), Estudios Palinológicos. Universidad de Alcalá de Henares, Alcalá de Henares, pp. 101-105.

Pantaleón-Cano, J., Yll, E.I., Pérez-Obiol, R., Roure, J.M., 2003. Palynological evidence for vegetational history in semi-arid areas of the western Mediterranean (Almería, Spain). The Holocene 13, 109-119.

Parra, I., 1994. Quantification des précipitations à partir des spectres polliniques actuels et fossiles: du Tardiglaciaire à l'Holocène Supérieur de la côte méditerranéene espagnole. Ph.D. thesis, Université de Montpellier, Francia.

Pausas, J.G., Keeley, J.E., 2009. A burning story: the role of fire in the history of life BioScience 59, 593-601.

Peinado Lorca, M., Rivas-Martínez, S., 1987. La vegetación de España. Servicio de publicaciones de la Universidad de Alcalá de Henares, España.

Peña-Chocarro, L., Zapata Peña, L., Iriarte, M.J., González Morales, J., Straus, L.G., 2005. The oldest agriculture in northern Atlantic Spain: new evidence from El Mirón Cave (Ramales de la Victoria, Cantabria). Journal of Archaeological Science 32, 579-587.

Peñalba, M.C., 1994. The history of the Holocene vegetation in northern Spain from pollen analysis. Journal of Ecology 82, 815-832.

Peñalba, M.C., Arnold, M., Guiot, J., Duplessy, J.C., de Beaulieu, J.L., 1997. Termination of the last glaciation in the Iberian Peninsula inferred from the pollen sequence of Quintanar de la Sierra. Quaternary Research 48, 205-214.

Pérez-Obiol, R., Julià, R., 1994. Climatic change on the Iberian Peninsula recorded in 30, 000-yr pollen record from Lake Banyoles. Quaternary Research 41, 91-98.

Piqué, R., 2005. Paisaje y gestión de recursos forestales entre el VI y IV milenio cal. BC en el nordeste de la Península Ibérica. In: Ontañón Peredo, R., García-Moncó Piñeiro C., Arias Cabal, P. (Coords.) Actas del III Congreso del Neolítico en la Península Ibérica. Santander, pp. 45-52.

Pons, A., Reille, M., 1988. The Holocene and Upper Pleistocene pollen record from Padul (Granada, Spain): a new study. Palaeogeography, Palaeoclimatology, Palaeoecology 66, 243-263.

Postigo, J.M., Gómez Manzaneque, F., Morla, C., 2008. Survival and long-term maintenance of tertiary trees in the Iberian Peninsula during the Pleistocene. First record of Aesculus L. (Hippocastanaceae) in Spain. Vegetation History and Archaeobotany 17, 351-364.

Provan, J., Bennett, K.D., 2008. Phylogeographic insights into cryptic glacial refugia. Trends in Ecology and Evolution 23 (10), 564-571.

Ramil-Rego, P., Taboada Castro, M.T., Aira Rodríguez, M.J., 1993. Estudio palinológico y factores de formación de la turbera de Gañidoira (Lugo, España). In: Fumanal, M.P., 
Bernabeu, J. (Eds.), Estudios sobre Cuaternario, medios sedimentarios, cambios ambientales, hábitat humano. Universitat de València, València, pp. 191-197.

Ramil-Rego, P., Múñoz Sobrino, C., Rodríguez-Guitián, M., Gómez-Orellana, L., 1998. Differences in the vegetation of the North Iberian Peninsula during the last 16, 000 years. Plant Ecology 138, 41-62.

Ramil-Rego, P., Rodríguez Guitián, M.A., Muñoz-Sobrino, C., Gomez Orellana, L., 2000. Some considerations about the postglacial history and recent distribution of Fagus sylvatica in the NW Iberian Peninsula. Folia Geobotanica 35, 241-271.

Reed, J.M., Stevenson, A.C., Juggins, S., 2001. A multi-proxy record of Holocene climatic change in southwestern Spain: the Laguna de Medina, Cádiz. The Holocene 11, 707-719.

Rey Benayas, J.M., Scheiner, S.M., 2002. Plant diversity, biogeography and environment in Iberia: patterns and possible causal factors. Journal of Vegetation Sciences 13, 245-258.

Rodríguez-Ariza, M.O., 1992. Human-plant relationships during the Copper and Bronze Age in the Baza and Guadix basins (Granada, Spain). Bulletin de la Société Botanique de la France 139, Actualités botaniques (2-3-4), pp. 451-464.

Rodríguez-Ariza, M.O., 1995. Análisis antracológicos de yacimientos neolíticos de Andalucía. Rubricatum 1, 73-83.

Rodríguez-Ariza, M.O., 2000. El paisaje vegetal de la Depresión de Vera durante la Prehistoria reciente. Una aproximación desde la antracología. Trabajos de Prehistoria 57, 145-156.

Rodríguez-Ariza, M.O., Vernet, J.L., 1991. Etude paléoécologique du gisement chalcolithique de Los Millares (Santa Fé de Mondújar, Almería). In: Waldren, W.H. Ensenyat, J.A., Kennard, R.C. (Eds.), Recent developments in western Mediterranean prehistory: archaeological techniques, technology and theory. : BAR International Series, vol. 573. Oxford, pp. 1-16.

Ros Sala, M.M., 2008. La Punta de Los Gavilanes: un asentamiento en el tiempo en el litoral de la Bahía de Mazarrón (Murcia). Memoria Arqueológica de las campañas de trabajo 1998-2004. Dirección General de Bienes Culturales y Museos de la CARM, Murcia.

Rubiales, J.M., García-Amorena, I., Génova, M., Gómez Manzaneque, F., Morla, C., 2007. The Holocene history of highland pine forests in a submediterranean mountain: the case of Gredos mountain range (Iberian Central range, Spain). Quaternary Science Reviews 26, 1759-1770.

Rubiales, J.M., García-Amorena, I., García Álvarez, S., Morla, C., 2009. Anthracological evidence suggests naturalness of Pinus pinaster in inland southwestern Iberia. Plant Ecology 200, 155-160.

Ruíz-Zapata, M.B., Farias, P., Jiménez Sánchez, M., Gil-García, M.J., Dorado-Valiño, M. Valdeolmillos Rodríguez, A., 2001. Secuencia polínica de un depósito de la depresión de Comeya (Picos de Europa, Asturias): implicaciones paleoclimáticas. In: Moreno Grau, S., Rendueles, B., Moreno Angosto, J.M. (Eds.), XIII Simposio de la Asociación de Palinólogos de Lengua Española (A.P.L.E.). Universidad Politécnica de Cartagena, Cartagena, pp. 379-389.

Ruíz-Zapata, M.B., Gil, M.J., Dorado, M., Valdeolmillos, A., Vegas, J., Pérez González, A 2002. Clima y vegetación durante el Tardiglaciar y el Holoceno en la Sierra de Neila (Sistema Ibérico Noroccidental). Cuaternario y Geomorfología 16 (1-4), 9-20.

Ruíz-Zapata, M.B., López-Sáez, J.A., Vegas, J., López-García, M.J., Pérez González, A., GilGarcía, M.J., Dorado, M., Valdeolmillos, A., 2003a. Environmental changes during the Late Glacial-Holocene transition in Sierra de Neila (Laguna Grande lacustrine record, Spain). In: Ruíz-Zapata, M.B., Dorado, M., Valdeolmillos, A., Gil, M.J., Bardají, T., Bustamante, I., Martínez, I. (Eds.), Quaternary climatic changes and environmental crises in the Mediterranean region. Universidad de Alcalá de Henares, Ministerio de Ciencia y Tecnología, INQUA, Alcalá de Henares, pp. 139-147.

Ruíz-Zapata, M.B., Ortega Martínez, A.I., Dorado, M., Valdeolmillos, A., Gil-García, M.J. Arsuaga, J.L., Carretero Díaz, J.M., Martínez Mendizábal, I., Pérez González, A. 2003b. Vegetational history during Bronze and Iron ages in Portalón cave (Sierra de Atapuerca, Burgos, Spain). In: Ruiz, M.B., Dorado, M., Valdeolmillos, A., Gil, M.J. Bardají, T., de Bustamante, I., Martínez-Mendizábal, I. (Eds.), Quaternary Climatic Changes and Environmental crises in the Mediterranean Region. Universidad de Alcalá de Henares, Ministerio de Ciencia y Tecnología, INQUA, Alcalá de Henares, pp. 99-106.

Ruíz-Zapata, M.B. Gómez González C L López-Sáez J.A., Gil-García, M.J., Santiesteban, J.J Mediavilla, R., Dorado-Valiño, M., Valdeolmillos Rodríguez, A., 2006. Detección de la actividad antrópica durante el Holoceno reciente, a través de la asociación de palinomorfos polínicos y no polínicos en dos depósitos higroturbosos (El Berrueco y Rascafría) en la Sierra de Guadarrama, Madrid. Revista Española de Micropaleontología 38 (2-3), 355-366.

Sánchez-Goñi, M.F., Hannon, G.E., 1999. High-altitude vegetational pattern on the Iberian Mountain Chain (North-Central Spain) during the Holocene. The Holocene 9, 39-57.

Sánchez-Goñi, M.F., Cacho, I., Turon, J.L., Guiot, J., Sierro, F.J., Peypouquet, J.P., Grimalt, J.O. Shackleton, N.J., 2002. Synchroneity between marine and terrestrial responses to millennial scale climatic variability during the last glacial period in the Mediterranean region. Climate Dynamics 19, 95-105.

Santos, L., Sánchez Goñi, M.F., Freitas, M.C., Andrade, C., 2002. Cambios climáticos y vegetacionales en la zona costera de Melides (SO Portugal) durante el Holoceno. In: Valle, M., Rivas Carballo, M.R. (Eds.), Libro de Resúmenes del XIV Simposio de Palinología de la Asociación de Palinólogos de Lengua Española (APLE). Universidad de Salamanca, Salamanca, pp. 143-144.

Santos, L., Vidal Romaní, J.R., Jalut, G., 2000. History of vegetation during the Holocene in the Courel and Queixa Sierras, Galicia, northwest Iberian Peninsula. Journal of Quaternary Science 15 (6), 621-632.

Stevenson, A.C., 1985. Studies in the vegetational history of SW Spain. II. Palynological investigations at Laguna de las Madres, SW Spain. Journal of Biogeography 12 293-314

Stevenson, A.C., 2000. The Holocene forest history of the Montes Universales, Teruel, Spain. The Holocene 10, 603-610.
Stevenson, A.C., Moore, P.D., 1988. Studies in the vegetational history of S.W. Spain. IV. Palynological investigations at El Acebrón, Huelva. Journal of Biogeography 15, 339-361.

Stevenson, A.C., Harrison, R.J., 1992. Ancient forests in Spain: a model for land-use and dry forest management in south-west Spain from 4000 BC to 1900 AD. Proceedings of the Prehistoric Society 58, 227-247.

Stewart, J.R., Dalén, L., 2008. Is the glacial refugium concept relevant for northern species? A comment on Pruett and Winker 2005. Climatic Change 86, 19-22.

Tinner, W., Hu, F.S., Beer, R., Kaltenrieder, P., Scheurer, B., Krähenbühl, U., 2006. Postglacial vegetational and fire history: pollen, plant macrofossil and charcoal records from two Alaskan lakes. Vegetation History and Archaeobotany 15, 279-293.

Törnqvist, T.E., Janssen, C.R., Pérez Alberti, A., 1989. Degradación antropogénica de la vegetación en el noroeste de Galicia durante los últimos 2500 años. Cuadernos de Estudios Gallegos 38, 175-198.

Uzquiano, P., 1992a. Recherces anthracologiques dans le secteur Pyreneo-Cantabrique (Pays Basque, Cantabria et Asturias): Environnements et relations Homme-Milieu au Pléistocene Supérier et debut de l'Holocene. Ph.D. thesis, Université Montpellier, Francia.

Uzquiano, P., 1992a. The Late Glacial/Postglacial transition in the Cantabrian Cordillera (Asturias and Cantabria, Spain) based on charcoal analysis. Palaios 7, 540-547.

Valdeolmillos, A., 2004. Registro paleoclimático y paleoambiental de los últimos 350, 000 años en el Parque Nacional de Las Tablas de Daimiel (Ciudad Real). Ph.D. thesis, Universidad de Alcalá de Henares, Madrid.

Valdeón, J., Salrach, J.M., Zabalo, J., 1994. Historia de España IV: feudalismo y consolidación de los pueblos hispánicos (siglos XI-XV). Labor, Barcelona. 475 pp.

Valero-Garcés, B.L., Moreno, A., Navas, A., Mata, P., Machín, J., Delgado-Huertas, A., González-Sampériz, P., Schwalb, A., Morellón, M., Cheng, Hai, Edwards, R.L., 2008. The Taravilla lake and tufa deposits (Central Iberian Range, Spain) as palaeohydrological and palaeoclimatic indicators. Palaeogeography, Palaeoclimatology, Palaeoecology 259 (2-3), 136-156.

Valero-Garcés, B.L., Delgado-Huertas, A., Navas, A., Machín, J., González-Sampériz, P., Kelts, K., 2000a. Quaternary paleohydrological evolution of a playa lake, Salada Mediana, central Ebro Basin, Spain. Sedimentology 47, 1135-1156.

Valero-Garcés, B.L., González-Sampériz, P., Delgado-Huertas, A., Navas, A., Machín, J., Kelts, K., 2000b. Late Glacial and Late Holocene environmental vegetational change in Salada Mediana, central Ebro Basin, Spain. Quaternary International 73, 29-46.

Valero-Garcés, B.L., González-Sampériz, P., Navas, A., Machín, J., Delgado-Huertas, A., Peña-Monné, J.L., Sancho, C. Stevenson, A. Davis, B., 2004. Palaeohydrological fluctuations and steppe vegetation at the last Glacial Maximum in the Central Ebro valley (NE Spain). Quaternary International 122, 43-55.

van den Brink, L.M., Janssen, C.R., 1985. The effect of human activities during cultural phases on the development of montane vegetation in the Serra da Estrela, Portugal. Review of Palaeobotany and Palynology 44, 193-215.

van der Knaap, W.O., van Leeuwen, J.F.N., 1994. Holocene vegetation, human impact, and climatic change in Serra da Estrela, Portugal. Dissertationes Botanicae 234, 497-535.

van der Knaap, W.O., van Leeuwen, J.F.N., 1995. Holocene vegetation succession and degradation as responses to climatic change and human activity in the Serra de Estrela, Portugal. Review of Palaeobotany and Palynology 89, 153-211.

van der Knaap, W.O., van Leeuwen, J.F.N., 1997. Late Glacial and Early Holocene vegetation succession, altitudinal vegetation zonation, and climatic change in the Serra da Estrela, Portugal. Review of Palaeobotany and Palynology 97 (3-4), 239-285.

van der Schriek, T., Passmore, D., Stevenson, A.C., Rolão, J., 2007. The palaeogeography of Mesolithic settlement-subsistence and shell midden formation in the Muge valley, Lower Tagus Basin, Portugal. The Holocene 17, 369-385.

van Geel, B., Bohncke, S.J.P., Dee, H., 1981. A palaeoecological study of an Upper Late Glacial and Holocene sequence from De Borchert, The Netherlands. Review of Palaeobotany and Palynology 31, 367-448.

van Geel, B., Klink, A.G., Pals, J.P., Wiegers, J., 1986. An upper Eemian lake deposit from Twente, eastern Netherlands. Review of Palaeobotany and Palynology 46, 31-61.

van Geel, B., Coope, G.R., van der Hammen, T., 1989. Palaeoecology and stratigraphy of the Lateglacial type section at Usselo (The Netherlands). Review of Palaeobotany and Palynology 60, 25-129.

Vannière, B., Colombaroli, D., Chapron, E., Leroux, A., Tinner, W., Magny, M., 2008. Climate versus human-driven fire regimes in Mediterranean landscapes: the Holocene record of Lago dell'Accesa Tuscany, Italy. Quaternary Science Reviews 27, 1181-1196.

Willis, K.J., van Andel, T.H., 2004. Trees or no trees? The environments of central and eastern Europe during the Last Glaciation. Quaternary Science Reviews 23, 2369-2387.

Yll, E.I., Pérez-Obiol, R., Pantaleón-Cano, J., Roure, J.M., 1997. Palynological evidence for climatic change and human activity during the Holocene on Minorca (Balearic Islands). Quaternary Research 48, 339-347.

Yll, E.I., Carrión, J.S., Pantaleón, J., Dupré, M., La Roca, N., Roure, J.M., Pérez Obiol, R., 2003. Palinología del Cuaternario reciente en la Laguna de Villena (Alicante). Anales de Biología 25, 65-72.

Yll, E.I., Burjachs, F., Expósito, I., 2009. Descobrint els paisatges del passat. In: Marí, M. (Coord.), Vila i Ses Feixes. Els camins de l'aigua. GEN-GOB Eivissa. Eivissa, 19-40.

Zapata, L., 2002. Charcoal análisis from Basque archaeological sites: new data to understand the presence of Quercus ilex in a damp environment. In: Thiébault, $S$. (Ed.), Charcoal analysis. Methodological approaches, Palaeoecological results and wood uses. : BAR International Series, vol. 1063. Oxford, pp. 121-126

Zapata, L., Peña-Chocarro, L., Pérez, G., Stika, H.P., 2004. Early Neolithic agriculture in the Iberian Peninsula. Journal of World Archaeology 18 (4), 285-326. 